\title{
"Direito de Autor e Interesse Público nos Países em Desenvolvimento"
}

\author{
Carlos Alberto Bittar \\ Doutor em Direito pela Universidade de São Paulo \\ Professor Livre Docente na Faculdade de \\ Direito da USP \\ Membro efetivo do Conselho Nacional de \\ Direito Autoral
}

I - DIREITO DE AUTOR: NOCGOES BASICAS

1. Observações preliminares.

2. Direito de Autor: conceito e posição.

3. Direitos inseridos em seu contexto.

4. Obras protegidas.

5. Evolução.

6. Essência e alcance.

II - DIREITO DF AUTOR E INTERESSE POBLICO

7. O conflito entre o interesse páblico e o privado no Direito de Autor.

8. Limitações comuns decorrentes desse conflito.

9. As limitações nas convençôes internacionais e no direito interno dos paises em geral.

III - A SITUACGO NOS PAISES EM DESENVOLVIMENTO

10. A concepção «paises em desenvolvimento» no contexto da comunidade internacional.

11. Problemas peculiares a esses paises: alcance do interesse pablico.

12. A situação do conflito no plano do Direito de Autor.

13. Consequiências especificas desse conflito no plano internacional.

14. O regime especial instituido nas Convenções para esses paises: limitações e licenças legais.

15. A lei-tipo proposta pelas organizações internacionais.

16. Reflexos no direito interno dos paises em desenvolvimento.

17. Conclusões.

\section{I - DIREITO DE AUTOR: NOÇÕES BASICAS}

\section{Observações preliminares}

De há muito, vem-nos preocupando a posição do Direito de Autor assim como a de outros direitos privados - face a crescente inserção de noções e de elementos de ordem pública na respectiva disciplinação legal, de modo a comprimir a correspondente área de atuação. 
Interessa-nos, em particular, a situação daquele Direito nos países em desenvolvimento - em que se encontra o Brasil - a qual analisaremos no presente trabalho, procurando demonstrar os pontos de atrito existentes e os reflexos nas legislações nacionais.

Para esse efeito, partiremos de noções conceituais sobre o Direito de Autor, acentuando, ao depois, o conflito que nele se instala entre os interesses público e privado, o qual se traduz em limitações aos direitos de autor, ora inscritas em convenções internacionais e no direito interno de diferentes países.

Particularizando o tema, enfocaremos as conseqüências especiais desse entrechoque nos países considerados em desenvolvimento, com ênfase para as orientações observadas a nível do direito positivo, extraindo, ao final, as conclusões que nos parecem pertinentes na presente quadra de sua evolução.

Trata-se de tema de suma importância nos dias atuais, principalmente para os países em questão, porque é neles que mais se sente o conflito de interesses em causa, em função, de um lado, da necessidade de progresso da educação e da cultura como fatores fundamentais para o desenvolvimento geral da Nação - inclusive e especialmente mediante o aproveitamento de experiência alóctons - e, de outro, da imperatividade da concessão de proteção legal às criações intelectuais surgidas em seu contexto, exatamente como estimulo para a produção de obras de engenho pelos respectivos nacionais, na formação e na sedimentação de cultura autóctone, para a própria afirmação do país no cenário da inteligência mundial.

\section{Direito de Autor: conceito e posição}

Conforme salientamos em nosso livro «Direito de Autor na obra feita sob encomenda» (S. Paulo, Editora Revista dos Tribunais, 1977, p. 1), o Direito de Autor é o ramo da ciência jurídica em que se protege, sob os aspectos moral e patrimonial, o criador de obra literária, artística ou científica.

Acompanhando a própria evolução experimentada nas comunicações, o Direito de Autor tem-se afirmado, em concreto, nos tempos atuais, mostrando-se sensivel às conquistas do pensamento, da ciência e da arte. Insere-se, consoante a doutrina moderna, no contexto dos denominados «Direitos Intelectuais», ao lado do «Direito de Propriedade Industrial» (V. EDMOND PICARD: «Le Droit Pur», Bruxelles, F. Larcier, 1899, p. 98 e segs. espec. p.100; ARMINJON, NOLDE e WOLFF « «Traité de Droit Comparé», Paris, Librairie Générale, 1950, vol. I, p. 98 e segs. JEAN ESCARRA: «Droits intellectuels», Paris Librairie Delagrave, 1933, p. 230 e segs.; CARLOS MOUCHET e SIGFRIDO RADAELLI: «Derechos intelectuales sobre las obras literarias y artisticas», Buenos Aires, Abeledo Perrot, 1960, p. 71 e segs.; MARIO ARE «L'oggetto del Diritto di Autore», Milano, Giuffrè, 1963, p. 17; ISIDRO SATANOWSKY: «Derecho intelectual», Buenos Aires, Tipo- 
grafica Argentina, 1954, v. I, p. 113; MARCEL CRIONNET: «Les droits intellectuelles et les regimes matrimoniaux en droit français», Paris, Librairie Générale, 1975, p. 1; FILADELFO AZEVEDO: «Direito moral dos escritores», Rio, Alba, 1930, p. 10, dentre inúmeros outros autores).

Vislumbrado, sob certo aspecto, no mundo antigo, esse direito passou, com a invenção da imprensa e a conseqüente possibilidade de reprodução em série de obras, a traduzir-se em um sistema de privilégios concedidos a editores para a exploração econômica de criações literárias. (V., dentre outros autores, EUGENE POUILLET: «Traité de la proprieté littérarie et artistique», Paris, Librairie Générale, 1908, p. 1 e segs.: ÉDOUARD LABOULAYE: «Études sur la proprieté littérarie en France et en Angleterre», Paris, A. Dourand, 1858, p. 8 e segs.; LUIGI DI FRANCO: «Proprietà industriale, letteraria ed artistica», Milano, Società Editrice Libraria, 1936, p. 527 e segs.; PAOLO GRECO e PAOLO VERCELLONE: «I diritti sulle opere dell' ingegno», Torino, Torinese, 1974, p. 1 e segs.; CARLO CRISTOFARO: "Trattato del Diritto de Autore e d'inventore», Torino, Bocca, 1931, p. 8 e segs.; SAMUEL MARTINS: "Direito Autoral, seu conceito, sua história e sua legislação entre nós», Recife, Livraria Francesa, 1906, p. 6 e 7; ODDO BUCCI: «Interesse pubblico e Diritto d'autore», Padova, Cedam, 1976, p. 13 e segs.; K. STOYANOWITCH: «Le droit d'auteur dans les rapports entre la France et les pays socialistes», Paris, Librairie Générale, 1959, p. 21 e segs.).

Evoluiu, depois, no entanto, para, com a Revolução francesa, passar a proteger o autor da obra, como prerrogativa ligada à criação intelectual - e nos diferentes gêneros - graças, principalmente, ao labor que, naquele país, se desenvolveu em defesa dos direitos inerentes ao homem (V., dentre inúmeros autores, MARIE CLAUDE DOCK: «Etude sur le Droit d'auteur», Parios, Librairie Générale, 1963, p. 150 e segs.).

\section{Direitos inseridos em seu contexto}

O Direito de Autor compreende prerrogativas de ordem moral e de ordem patrimonial, aquelas relativas ao vínculo pessoal e eterno que une o criador à sua obra e, estas, referentes ao aproveitamento econômico da obra, mediante a participação do autor em todos os processos de utilização possiveis (como, dentre outras, consigna a lei brasileira especial: Lei 5.988, de 14-12-73: arts. 25 e segs. e 29 e segs).

Defluem dessa noção vários e distintos direitos, conhecidos por direitos morais e direitos patrimoniais. Os direitos morais estendem-se desde o direito de inédito até os de defesa da paternidade, de correção, de modificação e outros. Os direitos patrimoniais consubstanciam-se na faculdade de o autor usar ou autorizar a utilização da obra no todo ou em parte, dispor desses direitos a qualquer título e transmitir esses direitos a outrem, no todo ou em parte, entre vivos ou por sucessão 
(fórmula da Convenção de Washington de 1946, art. II). (V. a respeito, dentre inúmeros outros autores;VALÉRIO DE SANCTIS: «Diritto di Autore», in «Enciclopedia del Diritto», vol. IV, p. 378 e segs. e «Contratto di edizione», Milano, Giuffrè, 1965, p. 10 e segs.; GIUSEPPE PADELLARO: «Il Diritto d'autore (la disciplina giuridica di strumenti di comunicazione sociale»), Milano, Vallardi, 1972, p. 7 e segs.; GRECO e VERCELLONE: o. cit., p. 103 e segs.; ANDRÉ FRANÇON: «La proprieté littérarie et artistique», Paris, PUF, 1970, p. 45 e segs.; STIG STROMHOLM: «Le droit moral de l'auteur en droit allemand, français et scandinave», Stockholm, P. A. Norstedt \& Söners, 1966, v. I, p. 1 e segs.; STOYANO WITCH: o. cit. p. 30 e segs.; F. C. PONTES DE MIRANDA: "Tratado de Direito Privado», S. P., RT, 1977, V. XVI, p. 10 e segs.; J. M. CARVALHO SANTOS: "Código Civil Brasileiro interpretado», Rio, Freitas Bastos, 1963, vol. VIII, p. 403 e segs.).

Esses direitos são independentes entre si, fazendo nascer para o autor, cada qual, a remuneração correspondente; p. ex., os direitos de gravação e de execução pública, para as composições musicais; as edições gráficas e as representações para as obras teatrais; os direitos de adaptação, para cinema e para televisão, para as obras literárias e assim por diante.

Realizam-se, na prática, por formas as mais diversas, dentro dos dois processos fundamentais - a representação e a reprodução - com a extensa especificação hoje existente, em virtude do progressol das comunicações (v. a nossa obra cit. p. 27 e segs., em que os enunciamos).

\section{Obras protegidas}

As obras protegidas pelo Direito de Autor são as criações intelectuais de feição estética, dos domínios literário, artistico e científico (ARE: o. cit., p. e segs.; GRECO e VERCELLONE: o. cit., p. 36; TULLIO ASCARELLI: «Teoria de la concurrencia y de los bienes inmateriales», trad., Barcelona, Bosch, 1970, p. 634 e segs. V. tb. Lei brasileira 5.988/73: art. $6^{\circ}$ ).

Ampara esse Direito a forma original criada pelo autor, desde que o substrato ideológico é comum a todos (V. dentre outros autores: EDUARDO PIOLA CASELLI: «Tratado del Diritto di Autore e del contratto de edizione», Torino, Torinese, 1927, p. 205 e segs.; DE SANCTIS: o. cit., p. 7., RENEE - PIERRE LEPAULLE: «Le droit d'auteur sur son oeuvre», Paris, Dalloz, 1927, p. 21; ALLAIN LE TARNEC: «Manuel de la propreté littérarie et artistique», Paris, Dalloz, 1966, p. 177; ANDRÉ FRANÇON: o. cit., p. 9; HENRI DESBOIS: «Le droit d'auteur en France», Paris, Dalloz, 1966, p. 20 e segs.; CLOVIS BEVILAQUA: «Código Civil Comentado», Rio, Editora RIO, 1978, v.I, o. 1115 e PEDRO VICENTE BOBIO: «O Direito de Autor na criação musical», S. P. Lex, 1951, p. 13 e segs.).

As obras são protegidas independentemente do mérito ou da destinação (POUILLET: o. cit., p. 47: o. cit.; CASELLI: o cit., p. 62 e 
segs.; LE TARNEC: o. cit., p. 183; ARE: o. cit., p. 163 e segs., dentre outros escritores).

\section{Evolucão}

Fruto, para o autor, do liberalismo - que o descartou do editor, conferindo-lhe, ademais, foros de direito positivo - apresenta o Direito de Autor uma ratio especial: a da proteção do criador intelectual. Volta-se, desde então, essencialmente, para o amparo ao criador intelectual. Tem por meta específica o autor de obra de engenho (v. o nosso artigo «O Direito de Autor no plano das liberdades públicas», na Revista «Justitia», do Ministério Público do Estado de S. Paulo, $\mathrm{n}^{\circ}$ 98, p. 165 e segs., em que analisamos, em profundidade, a essência e a evolução do Direito de Autor. V t tb. ÉDOUARD SILZ: «La notion juridique de droit moral de l'auteur», in «Rev Tri. de Droit Civil», XXXII, p. 394; GEORGE MICHAÉLIDËS NOUAROS: «Le droit moral de l'auteur», Paris, Arthur Rousseau, 1935, p. 50; ISIDRO SATANOWSKY: o. cit., p. 14 e segs.; HERMANO DUVAL: «Direitos Autoriais nas invenções modernas», Rio Andes, 1965, p. 11 e 12).

Consagrou-se, pois, à épica do liberalismo (V. DOCK: o. cit., p. 150 e segs.; CRECO e VERCELLONE: o. cit., p. 7 e segs.), aparecendo como um dos direitos individuais, de ordem natural, mas positivado por seus autores, em face da preocupação de assegurar-se aos criadores os proventos defluentes da exploração econômica de suas obras.

Subjetivo e privatista, pois, ab origina, recebeu, logo, acolhimento doutrinário em todo o mundo civilizado, ao influxo da prevalência dos ideais de afirmação da pessoa humana.

Atingiu, também, a constitucionalização, em vários sistemas, alcançando depois o plano internacional, em que tem merecido várias Convenções - a primeira em Berna (formalizada em 1886), em que se fixaram os princípios fundamentais de sua estruturação - com sucessivas revisões periódicas, por meio das quais tem acompanhado, em sua estruturação, a evolução cultural e científica e o progresso das técnicas de comunicação (V. HENRI DESBOIS, ANDRE FRANÇON e ANDRÉ KEREVER: "Les conventions internacionales du droite d'auteur et des droits voisines», Paris, Dalloz, 1976, p. 9 e segs. NICOLA STOLIFI: "M Diritto di Autore», Milano, Società Editrice Libraria, 1932, V. I, p. 71 e segs. e 129 e segs.; CASELLI: o. cit., p. 13 e segs.; DESBOIS: o. cit., p. 872 e segs.; SATANOWSKY: o. cit., p. 17 e segs. STOYANOWITCH: o. cit., p. 41 e segs.; DOCK: o. cit., p. 116 e segs.; ANTONIO CHAVES: «Direito Autoral de Radiodifusão», S. Paulo R. T., 1952, p. 15 e segs., entre inúmeros outros autores).

Penetrou, depois, por força da projeção internacional e do impulso da doutrina e da jurisprudência, no direito interno dos países civilizados - inclusive dos ora denominados «países em desenvolvimento» - universalizando-se a sua regulação, por via de leis especiais, sempre impreg- 
nadas, no mundo ocidental, do subjetivismo apontado, por influência da União de Berna.

\section{Essência e alcance}

Consiste o Direito de Autor, em essência, em uma exclusividade concedida ao autor - ou a seus sucessores - pelo prazo da lei, para utilização econômica da obra, sujeitando-se, pois, à sua autorização toda e qualquer forma possível de aproveitamento, aliás, desde a concepção do mecanismo dos privilégios ( $\mathrm{V}$. dentre outros doutrinadores: STOLFI: o. cit., p. 10 e segs.; DI FRANCO o. cit., p. 593 e segs.; CASELLI: o. cit., p. 1 e segs.; SATANOWSKY: o. cit., p. 10 e segs.).

Ingressou no plano fático, pois como um monopólio, reconhecido primeiro ao editor e, depois, ao autor - - este, já no plano legislativo para a exploração econômica, por um certo prazo, de obras de sua criação. Foi, portanto, concebido e sufragado, em lei, como um direito próprio do autor, mas sujeito a limitação no tempo.

Ora, essas duas idéias - Matrizes marcam indelevelmente a sua estruturação, a saber: a) a exclusividade do autor para a exploração da obra e b) a delimitação no tempo dessa utilização, noções que refletem o eterno conflito, que em seu seio alberga, entre os interesses públicos e privados.

Com efeito, duas ordens de interesses - e conflitantes - ditaram essa orientação: a) o individual, do autor e b) o geral, da coletividade: aquele voltado para a proteção e para a retribuição econômica de sua obra; este, dirigido para a fruição, pela sociedade, dessa mesma obra.

Essa problemática colocou-se, desde logo, entre os seus fatores, gerando uma configuração toda especial para esse direito - e que se universalizou - na qual se procurou fazer uma síntese entre os interesses em questão, (V CASELLI: verpete "Diritto di Autore», in «Novissimo Digesto Italiano», vol. p. 676; POUILLET: o. cit., p. 169 e segs.; DOCK: o. cit., p. 150; MARTINS: o. cit., p. 3 e segs.; AZEVEDO: o. cit., p. 89).

Assim, na esquematização dos pontos vitais desse direito, o choque de interesses evidenciou-se e emergiu sob a égide de duas premissas básicas e antagônicas: a) a primeira, de que o autor retira do acervo cultural da humanidade os elementos com que produz a sua obra, surgindo daí o direito à coletividade em dela desfrutar; b) a segunda, a de que a concepção e a criação da obra, como produtos do intelecto humano, devem propiciar ao autor, em sua exploração, os proventos correspondentes, reconhecendo-se também direitos personalíssimos ínsitos nessa mesma criação e que à lei cabe preservar.

Daí a textura toda própria que recebeu o Direito de Autor em que se identificam os traços privatísticos e publicísticos referidos - e cuja cristalização obedeceu, exatamente em função dos pressu- 
postos enunciados, a um longo processo evolutivo, que somente a a partir da segunda metade do nosso século tem atingido a necessária concretização (V. MARTINS: o. cit., p. 22 e segs., em que narra as vicissitudes da introdução legislativa desse direito entre nós; $V$. th. CASELLI: "Trattato», cit., p. 62 e segs.; STOLFI: o cit. p. 184 e segs.; DI FRANCO: o. cit., p. 594 e segs.; DESBOIS: o. cit. p. 21 e segs.; SATANOWSKI: o. cit., p. 17 e segs. e 32 e segs.; BEVILAQUA: o. cit., p. 1114 e segs.; HUGO WISTRAND: «Les exceptions apporteés aux droits de l'auteur sur ses oeuvres», Paris, Ed. Montchrestien, 1968, p. 13 e segs.; BUCCI: o. cit., p. 38 e segs. e 55 segs.; PADELLARO: o. cit., p. 3 e segs.; BOBBIO: o. cit., p. 7 e segs dentre outros autores).

Traduz-se, em síntese, em uma exclusividade que se reconhece ao autor - e a seus sucessores - para a exploração econômica de sua obra, mas por um certo prazo, vencido o qual cai ela no domínio público.

A exclusividade submete à autorização e à remuneração do autor, pelo lapso de tempo deferido, qualquer processo de utilização econômica da obra, considerando-se cada qual como gerador de um direito de autor, em virtude do princípio da independência dos direitos patrimoniais (de acordo com o qual, cada forma de utilização faz nascer um direito: assim, os direitos de reprodução - por meio gráfico, fotográfico, rotográfico e outros - e os de representação - por teatro, por televisão e outros meios) (V. o nosso livro cit. p. 27 e segs.; J. G. RENAULD: «Droit d'auteur et contrat d'adaptation», Bruxelles, F. Larcier, 1955, p. 137 e segs.; V. tb. a Lei brasileira $\mathrm{n}^{\circ}$ 5.988/73: art. 35, que expressamente assim dispõe).

Procurou-se, com isso, uma conciliação entre os interesses individuais do criador e os da coletividade - estes voltados para o progresso e a difusão da cultura - conferindo-se-lhe o monopólio, mas por um certo lapso de tempo, após cujo implemento passa a obra ao domínio da comunidade, podendo, em princípio, por qualquer de seus membros, ser utilizada.

\section{II - DIRETTO DE AUTOR E INTERESSE DO PÚBLICO}

\section{O conflito entre o interesse público e o privado no Direito de Autor}

Nessa constante preocupação de síntese entre os interesses em causa, reside, pois, o ponto de crise do Direito de Autor, que, ab origine ein assentia, exibe em seu contexto os estigmas desse conflito, consubstanciados em limitações e derrogações que lhe são impcstas em concreto, muitas na própria Convenção de Berna e em suas revisões (WISTRAND: o. cit., p. 7 a 9; BUCCI: o. cit., p. 55 e segs.; SATANOWSKY: o. cit., p. 32 e segs.).

Nesse passo, aliás, o Direito de Autor reflete o mesmo posicionamento de outros direitos privados, que têm sofrido o influxo do interesse coletivo, o qual, paulatinamente, vem traçando balizas ao es- 
pirito essencialmente liberal que o estruturou e o estratificou em norma, inobstante as manifestações legais protecionistas que, com razão, cercam os interesses individuais do autor em seu relacionamento com as pessoas e as empresas em cuja atividade a matéria-prima básica é a obra intelectual (V. os nossos artigos «Interpretação no Direito de Autor»», in «Revista Forense», n" 266, p. 67 e segs. e «O Dirigismo econômico e o Direito contratual», in «Revista dos Tribunais», $\mathrm{n}^{9} 526$, p. 20 e segs.; e EDWYN S. HARWEY: «Derechos de Autor, de la cul" tura y de la information», Buenos Aires, Depalma, 1975, p. 30 e 31).

Com efeito, a própria evolução doutrinária por que tem passado a humanidade - após a admissão da intervenção do Estado na economia, para suprir as deficiências da iniciativa privada, vem sobrepondo o interesse coletivo ao individual, com o estreitamento, cada vez maior, de seu campo de ação, por meio de normas inspiradas por exigências públicas.

No Direito de Autor mais latente se mostra o conflito, exatamente porque, em seu contexto, o choque é direto e originário, refletindo, portanto, a luta eterna entre os interesses em questão, e que se manifesta sob as formas de limitações e de exceções aos direitos exclusivos assegurados aos autores, tanto nos países desenvolvidos, como nos em desenvolvimento e, nestes, acompanhados de fórmulas redutivas do nível de proteção, concebidas como mecanismos necessários para a sua integração às grandes convenções internacionais existentes.

Acentuam GRECO e VERCELLONE que esse posicionamento «non constituisce afatto un'anomalia, in quanto la possibilità di limitazioni à comune a tutti di diritti soggettivi in generale e specialmente a quelli che hanno parte della categoria dei diritti di esclusiva in senso lato, a partire dal diritto di proprietà».

Assinalam então que «i limiti trovano la loro ragione d'essere nel contrasto che, palese o latente, sempre esiste trala sfera dell'interesse individuale e quella dell'interesse sociale». (o. cit., p. 164).

De outro lado e com vistas à proteção da obra em si, como instrumento da cultura, verifica-se: a) uma objetivação desse Direito em alguns sistemas - ligados à orientação anglo-norte-americana, em que, aliás, obteve bem antes a regulamentação positiva enquanto que, em outros, b) vem mesclado a conotações ideológicas e concebido como instrumento de progresso do regime (nos países de inspiração soviética) (V. DOCK: «Radioscopie du Droit d'auteur contemporain», in «Il Diritto di Autore», 1974, no 4, p. 415 e segs.; V. tb. o nosso livro, cit., p. 46 a 49; CHAVES: o. cit., p. 28 e segs.; SATANOWSKY: o. cit., p. 11 e segs., dentre inúmeros outros doutrinadores).

Nos sistemas de inspiração anglo-norte-americana, o núcleo da proteção é a própria obra intelectual, revestindo-se, pois, de cunho essencialmente econômico os macanismos de defesa do autor previstos na legislação do «copyright», que ademais impõe formalidades para a 
sua concretização. A preocupação específica na matéria é, portanto, 0 aspecto patrimonial.

Mas, mesmo nos países subjetivistas, o Direito de Autor, mostra-se impregnado e entrelaçado com noções e elementos de caráter coletivo - em razão dos pressupostos enunciados - que lhe impõem certas limitações ou restrições, mesmo em pontos substanciais, como adiante verificaremos.

Com efeito, há o incontestável interesse coletivo na difusão de obras intelectuais; existe a necessidade de acesso de diferentes camadas populacionais - principalmente professores, estudantes e pesquisadores - aos texto e obras públicas; e impõe-se a expansão da cultura como esteio do desenvolvimento geral da nação, conforme acentuamos em nossa tese «Reprografia e Direito de Autor»: uma proposta para a regulamentação legal da matéria» in «Revista da Procuradoria Geral do Estado», n 10, p. 459 e segs.; e Revista «Il Diritto di Autore», 1981, p. 502 e segs., como o título «Reprographie et Droit d'auteur: une proposition pour la reglementation legale de la matière»).

Nesse sentido, anotam GRECO e VERCELLONE: «la disciplina positiva dei risultati dell'atività dell'ingegno umano è state sempre ed ovunque il frutto de uma scelta e spesso di um compromesso tradue esigenze tra loro contrastanti: l'interesse della coletività ad utilizzare liberamente ed imediatamente il risultado, l'interesse dell'autore a riservarne a sé l'utilizzazione economica od almeno a trarre profitto dall'utilizzazione altrui. La prima esigenza, com' è logico, tende a prevalere quando appare più pressante l'interesse della colletività, in tal caso rifiutandosi all'autore ogni pretesa a diritti esclusivi di utilizzazione, i riducendone assai il contenuto o la durata. Al contrario si perviente con minore resistenze ad attribuire ampie e più durevoli esclusive a favore dell'autore quando il contrastante interesse della colletività, pur se esiste, è assai meno rilevante, si che se giustifica la più energica affermazione di un diritto dell'autore» (o. cit., p. 36 e 37).

Nessa mesma diretriz, acentua PIOLA CASELLI que «l'esercizio del diritto di autore può urtare, in casi particolari, contro talune, specifiche esigenze della vita sociale, le quali moderano o modificano l'esercizio stesso» (o. cit., p. 503).

Lembrando, ademais, que as limitações são comuns a todos os direitos privados, acentua adiante que: «tale temperamenti del diritto di autore hanno natura logica e giuridica, diversa da quelli compresi nella rubrica della utilizzazione» (que também importam em exceções ao citado Direito). E argumenta: «Essi infatti, non come questi secondi immanenti nella natura del diritto, si da venire necessariamente in considerazione nella sua construzione giuridica, bensi disquali agiscono, spesso, in modo speciale per talune aper o per talune categorie di autori. Perciò, mentre la libera utilizzazione, contemperata con i diditti esclusivi, dà origine alle regole normalio del loro 
esercizio, questi temperamenti speciali, di interesse publico intervengono a modificare in linea di eccezione le regole stesse». (o. cit.; p. 36 e 37.

Rematando, observa:

«Detta diversità há una pratica importanza giuridica, per chè rederiva che le limitazioni che vanno sotto la rubrica della libera utilizzazione, sicome necessarie e normali, possano essere argomentate con larghezza estensiva di concetti dai principi generali dell'istituto, ed invece, quest'altre modificazioni, straordinarie ed eccezionali, non devono ammettersi che in stretta e vigile misura, vuoi sulla base di un'expressa disposizione della quale risulti la volontà dello stato, come rappresentante gli interessi colletivi, di derrogare, per speciale esigenze di datti interessi, al diritto privato dell'autore; vuoi sulla base di indiscutibili esigenze della vita sociale». (o. cit., p. 504).

\section{Limitaç̃oes comuns decorrentes desse conflito}

Por essa razão é que interesses de caráter público têm imposto balizas aos direitos autorais ao longo dos tempos, em todos os países, as quais se refletem no direito positivo, por meio de formulação de regras de exceção, que vem a mitigar o caráter absoluto da exclusividade conferida ao autor (V o nosso «Limitações aos direitos autorais», verbete in «Enciclopédia Saraiva do Direito», vol. 50, p. 32 e 33; BUCCI: o. cit., p. 1116; STOLFI: o. cit., v. II, p. 622 e segs., dentre outros autores).

Por isso, registra ROBERT PLAISANT que, de um lado, o Direito de Autor «interdit tout reproduction ou toute répresentation de l'oeuvre sans l'autorisation de l'auteur», mas, de outro, «ce droit, exclusif et absolu, dans sons principe, comporte certaines exceptions» ( $\ll$ Le droit des auteurs et des artistes 'xécutantes», Paris, J. Dalmas, 1970, p. 24).

Salienta, ao depois, que essas limitações se fundam em diversas idéias, dentre as quais a de que «des facilités minimales doivent être données pour l'utilisation des oeuvres à des fins documentaires, charitables ou culturelles» (p. 25).

Versando a matéria, alguns autores procuram sistematizar as limitações que se impõem aos direitos do autor.

Assim, MOUCHET e RADAELLI, depois de assinalar que são ditadas por «razones superiores a las conveniencias de los particulares», régistram que essas restrições «pueden clasificarse en dos grupos». $\mathrm{E}$ frisam: «En uno están los impuestos en los mismos leyes regulamentarias de los derechos del autor y que se fundam en exigencia de interés cultural o informativo. En otro los derivados de exigencias dal ordes pública, como son los que impone la policia de costumbres y las que resultam del control gubernativo sobre determinados aspectos de la actividad intelectual, por razones de gobierno o de administración» 
(«Derechos intelectuais sobre las obras literarias y artisticas», Buenos Aires, Guillermo Kraft, 1948, v. II p. 131 e 132).

Anota ALAIN LE TARNEC, em tentativa de síntese, referindo-se à atual lei francesa (art. 41), que: «Le droit exclusif de reprodution dont est titularie l auteur cède devant un certain nombre d'impératifs, soit qu'ils tiennent un caractere strictemente privê de la reproduction, soit qu'ils résultent des necessités de l'instruction on de l'information, soit qu'ils se trouvent commandés a par la nature das choses» (o. cit., p. 85).

Assinalam outros autores, como GRECO e VERCELLONE, sem preocupação de classificação, que a superposição desses interesses públicos atinge o Direito de Autor ainda na fase da exclusividade, acentuando:

«Codesti interessi sono più vari: qualche volta si tratta di interessi strettamenti personali di terzi, ma il più spesso di interesse che sono d'ordine pubblico o che, almeno, pur rientrando nella sfera della iniziativa privata, si fondano su ragioni di utilità collettiva, interesse politici, economici, culturali, educativi, religiosi, d'informazione, ecc.» (o. cit., p. 165).

Essas limitações variam, em concreto, conforme as legislações, que, como acentua WISTRAND, procuram:

«Faciliter au créateur l'épanouissementéa de ses dons et met á sa disposition les moyeus d'en tirer les bénéfices». Mas ressalta que «comme tous les droits privés, le droit d'auteur a des exceptions» e que os principios «qui les fixent depend, pour chaque législation, l'extension de la sphere des droits du créateur», sempre em função da exigência da comunidade (o. cit., p. 40).

Mas, de um modo geral, conforme observa SATANOWSKY, a obra intelectual cumpre finalidades benéficas a «los costumbres sociales y la cultura estética» especialmente, «la educacion de los niños, infantes y adolescentes, mediante el material pedagógico destinado a la escuela - y el ético - factor de la educación moral» (o. cit., p. 33).

Discorrendo sobre os fundamentos desses posicionamentos, BUCCI registra a discussão sobre o alcance do interesse público e anota duas posições: uma, que: «ravvisa proprio nell'interesse pubblico al progresso culturale della colletività le ragioni giustificative della tutela», outra que «il pubblico interesse interverrebbe soltanto per giustificare le limitazioni legali del diritto di autore» (o. cit., p. 58).

Discutindo depois as várias hipóteses da lei italiana (o. cit., p. 64), realça que: «tutte queste disposizioni imporgono vere e proprie restrizioni al diritto di autore; esse rispondono, come si è datto, a finalità di pubblico interesse, quali la difusione della cultura, la libera circolazione delle idee e l'appendimento di esse da parte di tutti i consociati, sul pressuposto che le opere dell'ingegno individuale sono parte del patrimonio culturale comune, che deve essere reso accessíbile a tutti» (p. 65). 
De nossa parte, temos acentuado, com base na legislação brasi. leira (Lei 5.988/73, art. 49), que, das limitações, a) uma reveste-se de caráter institucional, decorrente da própria conceituação desse direito; e b) outras se aliam a exigências da cultura, da censura, do ensino e de outras considerações de ordem pública ( $\mathrm{V}$ o nosso verbete citado), presentes, aliás, nas Convenções internacionais e, praticamente, em todas as legislações do mundo civilizado.

Assim, de início, a partir da noção de que o autor retira elementos do acervo cultural preexistente, tem sido sufragrada, à unanimidade, como institucional, a limitação no tempo dos direitos patrimoniais de autor, para efeito de aproveitamento ulterior da obra pela coletividade (como ínsita em sua própria essência). Retira-se ao autor - ou a seus sucessores - a exclusividade de exploração - após certo prazo, e a obra cai no domínio público.

Exigência da coletividade impõem, ainda, outras limitações aos direitos autorais, inclusive quanto a obras que poderiam ser consideradas em seu contexto, como discursos e outras criações dessa ordem, notícias de jornais, cartas e certas inserções em publicações periódicas.

Da vida pública decorrem, aliás disso, limitações concernentes à censura e ao controle de comunicações. De ordem didática são as relativas e coletâneas e antologias. De cunho científico, as citações e as críticas e assim por diante.

Todas essas limitações se relacionam, pois, em última análise, com os objetivos maiores de difusão de conhecimentos e de disseminação de cultura, como verdadeiro tributo a que se sujeita o autor em favor da coletividade, de cujo acervo geral retira elementos para as criações de seu intelecto.

Subsistem, nesse elenco, a referida limitação institucional - que diz respeito ao prazo de duração do direito de exclusividade de esploração, variável nas legislações nacionais (entre nós: lei cit., arts. 42 e segs.) - e as especiais, referentes a aspectos particulares de utilização da obra pelo público em geral ou por certas categorias, previstas, sempre, de modo expresso e com interpretação restrita, nas legislações nacionais, como limitações que a coletividade põe ao exercício dos direitos de autor, como registra CASELLI (o. cit., p. 503 e segs.) (. tb. DESBOIS: o. cit., p. 280 e segs.) e segs.; DONALD F JOHNSTON: «Copyright Handbook», New York and London, R. R. Bowner Co., 1982, p. 30 e segs.; PEDRO ORLANDO: «Direitos Autorais» S. Paulo Nova Jurisprudência, s/ data, p. 19 e segs.; K. STOYANOVITCH: o. cit., p. 117 e segs.; dentre outros autores).

Mas, de qualquer sorte, não se revestem de caráter econômico mesmo que possam advir, e por via de reflexo, resultados da utilização - destinando-se, ao revés, a objetivos sociais definidos e relacionados à idéia geral de interesse coletivo, na divulgação e na absorção de conhecimentos que da obra defluam.

Por essa razão básica é que escapam ao âmbito de incidência do Direito de Autor, que, como assinala MARIO FABIANI, alcança so- 
mente as situações em que exista aproveitamento econômico da obra ( Note in tema di Diritto di Autore, interesse sociale e tutela della personalità», in «Il Diritto di Autore», 1975, p. 164; V. tb. CASELLI: o. cit., p. 503).

Sua justificação encontra razões várias na doutrina, inclusive em posições sociais adotadas por alguns escritores na análise da natureza do Direito de Autor (V. dentre inúmeros outros autores; STROMHOLM: o. cit., I, p. 102 e segs.; STOLFI: o. cit., I, p. 71 e segs. e II, p. 246 e segs; DI FRANCO: o. cit., p. 677 e segs., e 726 e segs.; POUILLET: o. 169 e segs., e 211 e segs.; ANTONIO DE ALMEIDA SANTOS: «Ensaio sobre o Direito de Autor», Coimbra, Coimbra Ed., p. 6 e segs.; HILTON FERNANDES: «Pressupostos do Direito Autoral de execução pública», Belo Horizonte, 1968, tese, p. 48 e segs.; J. MOLAS VALVERDE: «Normas procesales de especializacion en propriedad intelectual», Barcelona, Nauta, 1968, p. 13), relacionando-se, basicamente, com a reciprocidade de interesses na interação autor-comunidade, apontada por WISTRAND, que salienta que "en même temps que sera satisfaite une prétension juste du créateur, I'appvi qui lui est prêté de la part de la communaute est avantageuse pour celle-ci» (o. cit., p. 51).

Por isso, anota o mesmo autor que «rien n'empêche en effet qu'une règle comportant des conséquences positives pour l'un des parties ne puisse égalament être avantageuse pour l'autre. C'est ainsi que certaines restrictions au droit du créateur, par exemple en faveur de l'éducation populaire, peuvent, en fin de compte, se montre avantageuses pour celui-ci» (o. cit., p. 52).

Aliás, desde o início da internacionalização do Direito de Autor e na própria realização da Convenção de Berna, já se reclamavam limites à proteção absoluta do autor, justificados pelo interesse público, conforme relata NUMA DROZ (na «Ata da Conferência de Berna», 1885, p. 29, sessão de 18-09-1885, p. 29, sessão de 18-09-1884) (sobre a internacionalização V. dentre outros: STOLFI: o. cit., II, p. 780 e segs.; DI FRANCO: o. e loc. o. cit; POUILLET: p. 905 e segs. STROMHOLM: o. cit., II., p. 365 e ses.; DESBOIS: o. cit., p. 889 e segs; SATANOWSKY: o. cit. I. p. e segs; DESBOIS, FRANÇON e KEREVER: o. cit., p. 10 e segs.).

Não se pode, por fim, esquecer das fendas que, na prática, vêm sendo abertas na muralha protetora do Direito de Autor - estudadas por diferentes autores, como BUCCI (o. cit.) e PADELLARO (o. cit.) - face aos diferentes processos de comunicação da obra ao público que a tecnologia vem introduzindo sucessivamente, com reflexos diretos nos direitos patrimoniais do autor (de que cogitamos, oferecendo sugestōes para o seu equacionamento, na tese «Os processos modernos de comunicação e o Direito de Autor», no «X Congresso Mundial de Direito», S. Paulo, 1981, publicada depois em várias revistas especializadas). 


\section{As limitações nas convenções internacionais e no direito interno dos países em geral.}

As limitações ao Direito de Autor encontram-se, ou inscritas nas próprias Convenções internacionais (no denominado iure conventiones), ou decorrem de seu sistema, ou, ainda, estão sufragadas no direito interno dos países em geral, tanto desenvolvidos, quanto em desenvolvimento (V. WISTRAND: o. cit., p. 52 e segs.).

Assim, de início, a própria Convenção de Berna abre espaço para essas limitações - respeitados sempre os direitos morais - possibilitando, por exemplo, a que os Estados convenentes permitam reproduções que não entravem, em concreto, a utilização normal da obra por seu titular, nem causem prejuizos injustificados a seus legítimos interesses (V. a respeito, a Convenção de Berna, com a redação da revisão de Paris, de 1971: art. $9^{\circ}$, alínea 2; V. tb.: DESBOIS, KEREVER e FRANÇON: o. cit., p. 185; e ORGANIZAÇÃO MUNDIAL DA PROPRIEDADE INTELECTUAL: «Guia da Convenção de Berna», trad., Genebra, 1980, p. 63).

Cuidando da livre utilização da obra intelectual em certos casos (art. 10), a Convenção assegura o direito de citação, desde que conforme aos bons costumes e se faça na medida justificada (alínea 1), facultando, outrossim, que as leis nacionais regulem as condições em que obras literárias ou artísticas possam ser licitamente utilizadas, a título de ilustração de ensino por meio de publicações, emissões radiofônicas ou gravações sonoras ou visuais, desde que conforme aos bons costumes (alínea 2).

Admite, ainda, a par de outras, que os Estados convenentes regulem as condições de utilização de obras vistas ou ouvidas em artigos de atualidade, de cunho econômico, político, ou religioso, transmitidos por jornais e por meio de radiodifusão (art. 10 bis, alínea 1), bem como as atualidades divulgadas pela fotografia e pela cinematografia (alínea 2).

Possibilita, ademais, depois de assegurar ao autor os direitos referentes à comunicação pública da obra pela radiodifusão, que possa o seu exercício ser substituído por licenças obrigatórias, garantindo-se, no entanto, os direitos morais e remuneração equitativa ao criador art. 11, bis, alínea 2).

Reserva, ainda, às legislações nacionais a disciplinação das gravações efêmeras feitas por organismos de radiodifusão (alínea 3 ).

Prevê, quanto a obras musicais, a possibilidade de licenças obrigatórias, para gravação sobre obras já gravadas, com ou sem palavras, preservada a faculdade do autor de obter remuneração (art. 13, alínea 1).

Dentre as lei nacionais, em que se inscrevem as limitações referidas, basta que se citem as dos Estados Unidos da América do Norte, de 19-1076, §§ 107 e segs.; Alemanha de 9-8-65, arts. 46 e 51; Ingla- 
terra: lei de 5-11-56, $\S \S 6$ e segs.; Itália, de 22-4-41: arts. 3,4 e 65 e segs.; França, de 11-3-57: art. 41; Japão, de 28-4-56.: arts. 30 e segs. Suécia, de 30-12-60, arts. 11 e segs.

De países considerados em desenvolvimento, mencionem-se, dentre as de números outros, as leis: do Brasil: lei cit., art. 49 (que reproduz enumeração antes contida no Código Civil: art. 666); do México, lei de 4-11-63: arts. 18 e 62; da Argentina, de 2-10-57.: art. 10; da Venezuela: lei de 12-12-62.: art. 43 e 49; do Chile, de 28-8-70., arts. 38 a 47; da Austrália, de 27-6-68 (modificada em 1977) : arts. 40 a 73; do Egito, de 24-6-54: arts. 11 a 17; do Senegal, de 4-12-73: arts. 10 a 14; da África do Sul, de 1965, seções 7 a 11 e 40 a 42; da Algéria, de 3-4-73, arts. 24 e segs; de Cuba, 8-12-77, art. 38; de Quênia, de 1-4-66, seções 7, 9 e 10; do Uruguai: lei de 15-12-37, art. 45; da Tunísia, de 14-2-66, arts 8 e segs.) (V a respeito, a resenha publicada pela ORGANIZACCÃO MUNDIAL DA PROPRIEDADE INTELECTUAL: "Copyright Law Survey», Genebra, 1979; e a da UNESCO «Repertório Universal de Derecho de Autor», Paris, 1968. V. tb. ARPAD. L. BOGSCH JR. e WILLIAM S. ROACH: «Diritto di Autore Internazionale», Milano, Giuffrè, 1956).

Com isso, dentro do espirito mencionado e sob a égide de intensa elaboração, de ordem internacional e mesmo nacional, estão sendo sufragados, até legislativamente, regimes especiais de licenças, outorgadas pelo Poder Público a interessados, para a utilização de obras protegidas, principalmente em países em desenvolvimento, mas também nos desenvolvidos e, nestes, sob pressão dos diferentes mecanismos de reprodução e de representação de obras intelectuais, que a técnica de comunicação vem introduzindo e aperfeiçoando continuadamente.

São as denominadas «licenças legais» ou «obrigatórias», ou «compulsórias», que ante a fatores vários ditados pelo interesse público, acabam por institucionalizar-se, vertendo-se o produto da arrecadação para os autores, por meio de mecanismo estatais de distribuição e, com isso, abrindo-se mais exceções ao regime de exclusividade.

Nesse sentido, já se encontram posicionadas certas leis, tanto de países desenvolvidos, como, principalmente, nos em desenvolvimento e, em particular, do continente africano.

Assim, ocorre por exemplo com as legislações de; Estados Unidos; lei de 19-10-76, seções 111, 115, 116 e 118; Alemanha; lei de 9-9-65, arts. 46,49 53 e 61; Suiça; lei de 7-12-22 (modificada em 24-6-55), arts. 17 a 20; Itália; lei de 22-4-41, arts. 52, 55, 56 e 58; Japão; lei de 6-5-70, arts. 33 e 67 e segs, e nos em desenvolvimento as de: Turquia: lei de 10-1251, arts. 41, 43 e 44; Bangladesh: Copyright Ordinance de 1962 e Copyright Act de 1974: seções 36 e 37; Zâmbia: Copyright Act de 1965: seção 7; Egito: lei de 1954: art. 35; India Copyright Act de 4-6-57: seções 31 e 52; México, lei de 1963: arts. 33 a 39; Tunísia: lei de 14-2-66: arts. 11 e 16; El Salvador: lei de 6-9-63: arts. 45 a 47; e Cuba: lei de 28-12-77: arts. 36 e 37 . 
Com essas licenças, retira-se ao autor a outorga da autorização, que passa à entidade estatal designada na lei, como forma de conciliação entre os interesses em causa, ficando, em principio, qualquer interessado habilitado a promover a utilização da obra, mediante requerimento, ou não, conforme o caso, mas sempre sujeito ao pagamento do valor nela estipulado como contrapartida.

Quando prevista na legislação e respectiva fórmula, à entidade competente caberá definir a licença, com o caráter de não exclusividade, aos requerentes, que ficam com o direito de utilizar a obra, nos termos ajustados, recebendo o autor a remuneração obtida, deduzidas as despesas de administração.

Por isso é que há autores - como GRECO e VERCELLONE que distinguem licença «legal» de licença «obrigatória», divisando a existência da primeira quando basta a permissão legal para a utilização, e caracterizando a segunda quando esta depende de decisão administrativa ou de ato de negociação (o. cit. p. 167).

Mas, especificamente para os países em desenvolvimento, têm sido adotadas, ainda, a nível internacional e mesmo nacional, certas orientações mitigadoras do rigor do Direito de Autor, em função das mesmas condições de conflito e também da situação peculiar de que esses países desfrutam no cenário mundial.

Deter-nos-emos, em seguida, nessa matéria, para penetrar em seus meandros e discutir o respectivo significado à luz da experiência jurídica e da realidade fática, assinalando, desde logo, que tem sido objeto de indagações e de estudos, por parte de juristas, administradores e interessados na temática do desenvolvimento, de que é pressuposto necessário a expansão da cultura.

\section{III - A SituAÇão NOS PAî́SES EM DESENVOLVIMENTO}

\section{A concepcão "países em desenvolvimento» no contexto da comunidade internacional.}

Para esse efeito, cumpre-nos, de início, indagar do próprio sentido e do alcance da noção «países em desenvolvimento».

Emergida com a inserção da problemática do desenvolvimento no Estado moderno e, em particular, com a obtenção de independência política das antigas colônias africanas, afirmou-se a expressão como designativa dos países ainda dependentes de tecnologia externa.

No seio das Nações Unidas, e consoante declaração adotada por sua Assembléia Geral em sessão de 13-11-63. ( $\mathrm{n}^{\circ}$ 1897), recebem essa conceituação os países cuja renda per capita seja inferior a 300 dólares por ano, e nos quais sessenta por cento da população se dedique à agricultura e viva na zona rural, e ainda com acentuado grau de analfabetismo. 
Embora criticada por doutrinadores, essa conceituação tem sido adotada no âmbito do Direito de Autor internacional, inclusive na última revisão das Convenções de Berna e de Genebra, realizada em Paris, em 1971 (V. VALERIO DE SANCTS: «Le revisioni di Parigi (Juglio 1971) della Convenzione Universale sul Diritto d'autore e della Convenzione di Berna, Atio di Stoccolmo», in "ח Diritto di Autore», 1972, p. 179, nota 38; PAOLA CRUGNOLA: «I Diritto d'autore nei paesi in via di sviluppo», in «n Diritto di autore», 1976, p. 219, nota 1; CARLOS MOUCHET: «Notes sur le Droit d'auteur en Amérique Latine», in «Le Droit d'auteur», 1971, p. 224), em que se remeteu a noção à prática estabelecida pela Assembléia Geral da O.N.U. (o caráter vago do conceito tem sido estigmatizado pela doutrina: V DE SANCTIS: 0 . cit., p. 179 e segs.; e N'DÉNÉ N'DIAYNE: «L'influence du droit d'auteur sur le développment de la culture dans les pays en voie de développment», in «Il Diritto di Autore,»1975, p. 275).

Por isso é que, de um modo geral, tem sido estendida a conceituação a países outros que, inobstante se não encontrem, rigorosamente, dentro dos parâmetros traçados, ainda não alcançaram desenvolvimento econômico suficiente, razão pela qual adotaremos a expressão «países em desenvolvimento» em consonância com o senso comum e face à realidade presente.

Registre-se que o conceito se aplica, com mais propriedade, aos novos Estados africanos, nascidos do processo de descolonização que se deflagrou especialmente na segunda metade do século atual, como

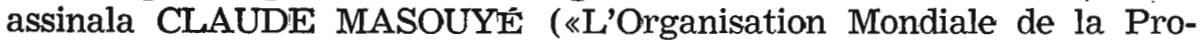
prieté Intellectuelle», in «Hommage a Henri Desbois», Paris, Dalloz, 1974, p. 323).

Contudo, tem-se como assente que nele se encartam também os países latino-americanos, e certos países da Ãsia, da India e da Austrália, a saber, aqueles que dependem de tecnologia alienígena para o desenvolvimento (denominados ainda de países do «Terceiro Mundo»). E nessa última acepção será tomada no presente estudo.

\section{Problemas peculiares a esses países: alcance do interesse público.}

Os países em desenvolvimento têm, em verdade, problemas próprios, principalmente os de independência mais recente, os quais lhes conferem situação peculiar no contexto das Nações.

Oriundos de antigos impérios coloniais europeus, defrontam-se com dificuldades de ordem econômica que - a par de outros fatores a insuficiência de tecnologia própria lhes impõe e, mesmo de afirmação cultural, que a longa influência alienigena lhes impinge.

Daí, as preocupações básicas, afloradas logo após a sua independência, de desenvolvimento econômico e de formação (preservação, ou afirmação) de cultura autóctone, na salvaguarda dos valores nacionais e a obtenção do almejado progresso geral, que dissipe, em de- 
finitivo, as sombras de dependência que ainda possam pairar sobre os seus horizontes.

Assim, as necessidades de desenvolvimento e de afirmação cultural - esta, mesmo, como premissa fundamental - têm lançado desafios profundos a essas nações a seus governantes, dando origem a posicionamentos especiais no âmbito do Direito de Autor.

Evidencia-se, desde logo, nesses países - e com ênfase maior o citado entrechoque de interesses, eis que, de um lado, existe a preocupação geral de difusão de conhecimentos e de aperfeiçoamento da ciência e da técnica como condicionantes do desenvolvimento e, de outro, a necessidade de amparar-se juridicamente o criador intelectual, a fim de que se sinta motivado a produzir, contribuindo, portanto, com seus dotes de engenho, para o alcance das metas assinaladas e para o próprio progresso cultural da nação.

De uma parte, esses países são obrigados a tomar medidas que favoreçam a disseminação de conhecimentos - inclusive a importação de textos e, precipuamente dos países desenvolvidos - e, de outro, a proteger os seus autores eficientemente para que encontrem estímulos para a criação intelectual e, ainda, instituir política adequada ao desenvolvimento do setor empresarial correspondente.

Ora, essa problemática eclode, exatamente, no campo do Direito de Autor, cujos esquemas se destinam a atender, como assinalamos, os direitos que defluem do trabalho intelectual.

Essas questões têm sido apontadas e discutidas, em especial, pelas organizações internacionais e pelos estudiosos da matéria na busca de orientações e de soluções para os países interessados.

Não pode, outrossim, em contraponto, deixar de consignar, nesse contexto, o interesse das grandes potências, preocupadas em assegurar às produções intelectuais os vastos mercados representados pelo expressivo contingente de países ainda em fase de desenvolvimento.

De fato, especialmente em relação ao continente africano, quando países desenvolvidos dispunham de mercados certos à época da dominação política, esse interesse de tal sorte ganhou vulto que acabou por gerar movimento internacional tendente a manutenção do citado manancial, mesmo depois de obtida independência das antigas colônias, traduzido, principalmente, por normas de exceção inseridas no plano do Direito de Autor, que adiante estudaremos.

$\mathrm{E}$ é com respeito a esses países que se cristalizaram, na definição de política própria para o setor cultural, orientações especiais tendentes a buscar o equilíbrio entre os interesses em questão, a partir dos anos setenta, como salienta HARVEY (o. cit., p. 7), e após a inserção da problemática desenvolvimentista como básica do Estado moderno.

Com efeito, acentua o citado autor: 
«El concepto de desarrollo nace como objetivo de una política en la decada de los años cinquenta, indentificado con los problemas de los países subdesarrollados desde el punto de vista económico y en terminos de un crecimiento de igual caracter», (o. cit., p. 6).

Anota, a seguir, que, nos anos setenta,

«la idea de considerar el desarrollo cultural de la comunidad como elemento integrante y parte vital del proceso de desarrollo general accede entonces rápidamente a su consagración como princípio de la acción internacional» (conforme conclusão da conferência intergovernamental sobre os aspectos institucionais administrativos e financeiros das políticas culturais, promovida pela UNESCO V. «Informe final», Paris; 1970).

Nesse sentido é que, nos Estados modernos, a cultura vem sendo vista como um dos direitos fundamentais do homem inscrito na Constituição e previsto em leis de planejamento - que ao Poder Central cabe garantir, enfatizando-se nesse contexto o papel relevante do Direito de Autor, como, dentre outros, ressaltam JOSÉ MARIA DESANTES: «La información como Derecho», Madrid, Ed. Nacional,1974, espec. p. 32; M. MOREIRA DA SILVA: «Código de Direito de Autor», Coimbra, Atlântica, 1955, p. 12; SATANOWSKY: o. cit., I, p. 17 e II, p. 253; VITTORIO M. DE SANCTIS: «Il Carattere creativo delle opere dell' ingegno», Milano, Giuffrè, 1963, p. 211 e segs.; BUCCI: o. cit., p. 55; LUIGI SORDELLI: "Diritto di autore, riproduzione di opere mediante la c. reprografia ed interessi personali e collettivi alla cultura», in «Il Diritto di Autore», 1975, p. 496 e segs.; GIOVANI GIACOBRE: «Interesse pubblico e interesse privato nella tutela del diritto di autore», mesma Revista, p. 520 e segs.; MASOUYÉ: o. cit., p. 323; ALFREDO ARIENZO: «Diritto di autore e problemi dell'informazione e della cultura di fronte alla nuove tecniche di riproduzione e diffusione delle creazioni intellecttuali», in «Il Diritto di Autore», 1975 p. 467 e segs. (sobre essa problemática, no plano internacional, dentre outros: MANUEL VALLEJO DIEZ DE VELASCO: "Instituciones de derecho internacionl público», Madrid, Tecnos, 1977 e P.F. GONIDEC: «Relátions internationales», Paris, Ed. Montchresten, 1974).

Logo se percebe, pois, que, nesses países, mais exacerbado se mostra o conflito entre os interesses público e privado, que acaba por originar a ideação e a consecução de mecanismo de compressão do Direito de Autor, tanto a nível internacional, como interno, ante às pressões existentes nos planos citados.

\section{A situação do conflito no plano do Direito de Autor}

Diferentes situações são detectadas na análise do Direito de Autor nos países considerados em desenvolvimento, exatamente em função de características próprias das diversas nações assim conceituadas.

Em perspectiva ampla, encontram-se mesclados, sob a mesma rubrica, países de todos os continentes, raças, costumes, convicções re- 
ligiosas e ideologias diversas, tornando-se difícil encontrar um denominador na identificação de sua posição e de seus problemas próprios com respeito à cultura, embora nela se apresente sempre o debate sobre a absorção, ou não, da experiência estrangeira e, na respectiva aceitação, o grau correspondente da saturação.

Com efeito, apartadas manifestações radicais, tem-se aceito, de um modo geral, o aproveitamento de conhecimentos externos no desenvolvimento do país, pois, como anota SATANOWSKY, a cultura nacional não deve descartar essa possibilidade (o. cit., v. I, p. 33).

Mas, no plano do Direito de Autor, podem-se alcançar certas orientações básicas, com referência à existência, à extensão, às limitações e ao prazo de duração dos direitos nesses países.

Assim, de um lado, alguns países, muito antes até da eclosão dessa problemática no plano internacional, já possuíam legislação própria sobre Direito de Autor, antecedendo, mesmo, a países ora definidos como o nosso Brasil, que, inicialmente, na lei que criou os cursos jurídicos em S. Paulo e em Olinda, de 1827, inseriu norma protetiva das lições proferidas pelos mestres, chegando, mais tarde, a normas penais no Código Criminal e a uma lei específica sobre esse Direito, em 1-8-1898, Lei $n^{0} 496$, até a inclusão da matéria no Código Civil, de 1916. Daí para cá, longo caminho percorreu o nosso legislador, editando normas em sucessivos e diversos diplomas legais, inclusive sobre os meios de comunicações, até chegar à atual lei central.

Outros países só bem mais tarde alcançaram a normatização na matéria (países das Américas, da Ãsia, da India e alguns da Ãfrica) e outros nem sequer contavam com um texto-base de regência, continuando, nesse passo, a égide do país de dominação (países do continente africano).

Outros, ainda, viram atentar para a problemática do Direito de Autor somente após a independência política (países africanos), lançando então legislação própria a respeito, e assim que se organizaram, após formalização de sua independência.

Obnubilados pela política de dominação, inclusive intelectual, exercida pelas potências colonizadoras, não tiveram esses países, com poucas exceções, condições de desenvolver suas próprias letras, suas artes e sua ciência. Não favoreciam as manifestações de nacionalidade, de um modo geral, as ações nesses países levadas a efeito pelo colonizadores, «introducendo nei Paesi dominati, insisme con la própria cultura, le loro legislazione in materia di diritto d'autore», como anota CRUGNOLA (o. cit., p. 220).

Com efeito, conforme assinala ZARA OLIVA ALGARDI, nos referidos países.

«Le opere dell'ingegno sono così numerose, nè destinate a una riproduzione così intensa tale da richiamare l'attenzione del legislatore per un 
progresso giuridico overo addirrittura per una legislazione in materia» ( «Il plagio letterario e il carattere creativo dell'opera», Milano, Giuffre, 1966, p. 280).

$\mathrm{E}$, adiante, acentua que:

«Le potense coloniali dalle quali alcuni di questi paesi hanno ereditato norme intese più che altro a tutelare i diritti dei colonizzatori, non hanno certo contributo ad accelerare presso quaesti populi una «coscienza» del diritto di autore, anche che hanno esteso ad alcuni paesi colonizatti le norme della Convenzione di Berna o alcune delle loro norme nazionale» (o. e loc. cit.).

Aperceberam-se logo de que necessária seria a adoção de lei sobre Direito de Autor, como forma de obter a sua afirmação como nação verdadeiramente assentada, por meio da proteção das criações intelectuais de seus nacionais.

Com efeito, conforme acentua CRUGNOLA - ao analisar a posição desse Direito nos países em desenvolvimento, enfocando a origem do referido movimento - com a sua independência «è avvenuto un profondo mutamento: il desiderio di un rápido e radicale rinnovamento si è diffuso in tutti i campi. Com isso, «i nuovo stati, consapevoli che questo scopo poteva essere raggiunto confidando, più ancora che nellaiuto straniero, nelle proprie forze e quidì, in campo culturale, attraverso una produzione letteraria e artistica nazionale, si sono resi conto che per incoraggiarla era necessaria una regolamentazione del diritto d'autore» (o. cit., p. 220).

Assim, simultânea ou sucessivamente, foram sendo baixadas, nos países africanos, leis especiais sobre a matéria, muito antes até de o direito legislado cobrir outros aspectos básicos da convivência humana (como as de: Zâmbia, 1965; Âfrica do Sul, 1965; Tunísia, 1966; Quénia, 1966; Algéria, 1973; Senegal, 1973, e outras).

A par disso e em consonância com a citada legislação - para efeito de obter a efetiva afirmação prática - começaram a ser edificados os respectivos sistemas administrativos próprios para a gestão dos direitos autorais e incluídos na estrutura central do Poder Executivo, sob a égide de um órgão especializado do Ministério correspondente (Educação e/ou Cultura), a saber os Conselhos Nacionais ou Oficinas centrais, encarregados de coordenar e fiscalizar as atividades do setor, em consonância com a política definida pelo governo para a área (V. dentre outros autores: N'DIAYE: o. cit., p. 277; E. NANA KOUANANG: «Réflexions sur le droit d'auteur et la protection du patrimoine culturel en Afrique», in «Le Droit d'auteur», 1976, p. 239 e segs.; ALI BENCHENEB: «Lettre d'Algérie», in «Le Droit d'Auteur», 1976, p. 242 e segs.; HARVEY: o. cit., p. 46 e segs. e FRED R. VON DER MEHDEN: «Politica de las nacions en vias de desarollo», Madrid, Tecnos, 1970).

Ademais, puseram-se a estimular as criações nacionais no sentido de obter a sua expansão, procurando obter resultados favoráveis no combate ao analfabetismo. 


\section{Como registra ALGARDI:}

«Nell' epoca contemporanea, che assiste al rapido risveglio di quei populi e alla loro ansia di rinnovamento e di rapida evoluzione, diverse exigenze sono invece tenute presenti, come quella di favorire l'instruzione e la cultura, di offrire ao cittadini senza alcun intralcio il massimo, come quantità e qualità, di opere dell'ingegno, scientifiche e letteraris. ..» (o. e loc. cit.,) .

Nas legislações editadas, tanto nas surgidas no começo do século, como nas advindas mais recentemente, nota-se sempre a preocupação de proteção como idéia-matriz, com limitações refinidas por expresso em cada qual, em função dos interesses assinalados, reconhecendo-se, nas leis mais modernas, os direitos morais do autor e especificando-se, em cada, prazos diferentes de duração dos direitos patrimoniais.

A tônica nas limitações é a da prevalência, nos pontos conflitantes, do interesse público, que ainda sustenta, em alguns regimes, as referidas licenças legais.

Nas leis mais atuais, sente-se forte influência da cultura e da experiência dos países antes dominantes, traduzida, inclusive, pela adoção das respectivas filosofias e terminologias na esquematização do texto: assim, por exemplo, as nações africanas de dominação inglesa aproximam-se do sistema do "Copyright», adotando, inclusive, o sentido patrimonial e a técnica de definições que o caracterizam; já os de influência latina, seguem a tradição ocidental, com fortes traços de subsunção ao sistema convencional de Berna, reconhecendo, por expresso, os direitos morais de autor, não prevendo formalidades para o reconhecimento e manifestando, ao longo de seus textos, a larga dose de subjetividade que o distingue.

Com efeito, a par de responder a exigências de sua estrutura social, econômica e política, como registra VALERIO DE SANCTIS ( «I bisogni dei Paesi in via di sviluppo nel campo della protezione internazionale del diritto di autore», in «Il Diritto di Autore», 1966, p. 549 e «L'évolution du droit d'auteur sur le plan intenational», Revista, 1970), as leis editadas nos países em desenvolvimento acatam, de um modo geral, os princípios fundamentais assentados no campo de Direito de Autor nas convenções e nas leis do países desenvolvidos, e, inobstante desatados os laços de dominação política, a verdade é que se ressentem, fortemente, da influência da tradição cultural dos ex-dominadores, enraizada pelo longo contato havido (V. no mesmo sentido, CRUGNOLA: o. cit., p. 221).

Assim é que, nos países africanos de independência mais recente, a par das disposições tradicionais, costumam aparecer, por expresso, normas tendentes a proteção do folclore, como nas leis da Tunísia; do Marrocos e da Algéria (sobre a matéria, V. GINO GALTIERI; «Folclore e diritto d'autore», in «Il Diritto di Autore», 1973, p. 391 e segs.).

Mas, o movimento não se restringe a países daquela região, vindo a atingir também outras nações, consideradas em desenvolvimento, 
dos continentes americano, asiático e australiano, gerando, ou a reformulação de textos já existentes, sempre no sentido de aperfeiçoamento do Direito de Autor e de adaptação do direito interno às conquistas internacionais que a evolução da matéria tem propiciado (como as leis de: Venezuela, 1963; México, 1963; Austrália, 1968, Chile, 1970; Brasil, 1973 e outros).

\section{Conseqüências específicas desse conflito no plano internacional.}

No plano das relações internacionais, os movimentos de independência das antigas européias na Ãfrica geraram a preocupação dos organismos internacionais em obter a adesão do enorme contigente de novos Estados que surgia, para integrá-los aos respectivos mecanismo e, com isso, alcançar a sua expansão, a par de intentar-se, como de seu objetivo precípuo, a preservação do equilíbrio entre as diferentes nações do mundo.

No âmbito do Direito de Autor, essa tendência foi logo destectada nas organizações correspondentes - no início, a U.N.E. S.C.D. e, depois, a O.M.P.I. - dando aso a diferentes estudos, congressos e trabalhos, desde _o início da década de sessenta, os quais culminaram com a insinuação de normas abrandadas no próprio contexto da Convenção de Berna, em favor dos países do denominado «Terceiro Mundo», a par da adoção de outras medidas tendentes a favorecê-los, inclusive a nível de definição de contornos para a respectiva legislação (elaboração de lei-tipo) e de assistência para a sua consecução.

Essas orientações conformam-se, aliás, aos objetivos mesmos das organizações internacionais existentes no plano do Direito de Autor, que, desde o início, se têm empenhado - como frisa MASOUYÉ em «fáciliter l'adaption par les législations de ce pays de lois régissant la propriéte intellectuele et leur permetant d'obtenir la technologie moderne dans les meilleurs conditions possibles, de participer de façon plus importante au commerce international et d'avoir accès de façon rapide et peu onéreuse à la production littétaire et artistique qui est nécessarie à l'éducation de leurs populations». (o. cit., p. 323).

Tal influência exerceu essa problemática sobre os Estados da União que, como acentua HENRI DESBOIS, ao deter-se sobre a matéria, que na situação dos países em desenvolvimento se encontra a gênese das duas últimas revisões da Convenção de Berna de Estocolmo (1967) e de Paris (1971), («Le Droit d'Auteur en France», mise a jour 1973», Paris, Dalloz, 1973, p. 79 e segs, em que analisa as disposições nelas estampadas para esses países).

Essas normas, tendentes a contribuir para a expansão dos países em tela, vinham sendo reclamados desde 1963, principalmente por nações da África (e defendidas, com ênfase, pela India), já nos trabalhos preparatórios da revisão da Convenção de Berna efetuada em Estocolmo, em 1967. 
Isso porque se encontravam essas nações, com a obtenção da independência, na ânsia de, um lado, de importar textos do exterior para o intercâmbio de idéias e, de outro, empenhados em produzir seus próprios, para o alcance dos objetivos propostos.

O movimento foi assentado na reunião de Brazzaville, promovida pelas organizações internacionais interessadas nessa problemática, sob o pressuposto de que as Convenções existentes eram aptas a responder, a interesses dos países exportadores de obras de espírito, devendo, pois, ser revistas, para preservar as dos países africanos, como concluíram os especialistas ali reunidos (V a recomendação no «Bulletin du droit d'auteur de l'Unesco», 1963, XVI, n² 2, p. 213).

Realça-se, nesse contexto, a proposta da Índia, formulada para a introdução, na Convenção de Berna - conforme resolução tomada em reunião efetivada em Nova Delli, em 1963 - de licenças obrigatórias para reprodução e normas sobre tradução, a exemplo das existentes na Convenção Universal (V. «Bulletin», cit., 1964, vol. XVII, p. 93).

As idéias básicas, que presidiam essas formulações, eram as de que o caráter rigoroso das legislações poderia levar: a) a seu desrespeito e b) a fazer-se traduções sem observância dos direitos protegidos; daí, a concepção de que normas mais brandas deveriam ser introduzidas nas Convenções.

Dentro desse espírito, ao longo dos anos, têm sido formuladas e, mesmo, concretizadas, no plano internacional, propostas tendentes a habilitar-se os Estados em desenvolvimento a, a) por meio de legislação interna mais amena, adotar política maciça de difusão cultural, com sacrifícios para os direitos de autor; e b) editar, consoante modelo oferecido (lei-tipo), legislação interna uniforme sobre esses direitos, inspirada em princípios já sedimentados nos países desenvolvidos cujos interesses sempre nortearam também essas orientações - mas para melhor atender à sua situação peculiar.

Assim é que, de uma parte, normas especiais para países em desenvolvimento têm sido inseridas nas convenções internacionais, em que se reduz o nível de proteção dos direitos de autor - por meio das licenças referidas - para facilitar-se a ação do Estado no interesse público de acesso aos textos e de difusão da cultura.

De outra parte, chegou-se à formulação de lei-tipo sobre Direito de Autor, que tem sido proposta como paradigma para as legislações nacionais dos países em questão, dentro da filosofia citada.

\section{O regime especial instituído nas Convenções para esses países: limitações e licenças legais.}

O passo inicial concreto, para a integração dos interesses desses países na Convenção, deu-se no Ato de Estocolmo (1967), sob o nome 
"Protocolo relativo aos Países em via de desenvolvimento», editado à época da revisão da Convenção de Berna realizada naquela cidade.

Esse Protocolo, agregado ao texto da Convençáo de Berna, inseriu, no direito convencional, normas excepcionais, limitativas dos direitos de autor em vários de seus aspectos patrimoniais.

Consistia em reservas que podiam opor os países em desenvolvimento a diferentes pontos, de sorte a permitir-lhes o gozo de regime especial sobre Direito de Autor, com a supressão, ou, pelo menos, a redução dos gravames mais sensiveis - a que se sujeitavam os Estados contratantes - que a sua situação econômica ou razões de ordem social e cultural não lhes possibilitassem manter (cf. GINO GALTIERI: «Il progetto di Atto Addizionale alla Convenzione di Berna», in «Il Diritto di Autore», 1970, p. 408, V. tb. CRUGNOLA: o. cit., p. 231; e, sobre os debates em Estocolmo, WISTRAND: o. cit., p. 123 e segs.; 140 e segs.; 164 e segs.).

As regras básicas do novo sistema giravam em torno: a) da duração da proteção, em que se previu prazo geral de cinqüenta a vinte e cinco anos; b) do direito de tradução, para o qual se instituiu licença legal remunerada; c) do direito de reprodução, com o tratamento semelhante; d) do direito de radiodifusão, respeitados os direitos morais e o pagamento de remuneração equitativa fixada por autoridade competente; e) utilização para ensino, estudos e pesquisas em todos os planos da educação, em que se conferiu às legislações nacionais a respectiva disciplina.

Como se observa, sensível redução no campo de abrangência dos direitos patrimoniais de autor representava a nova disciplinação, e, face à integração do Protocolo à Convenção, criou-se óbice intransponível à aceitação da revisão, que acabou por não merecer acolhida, pondo-a por terra todo o esforço desenvolvido no Ato de Estocolmo.

Com efeito, conforme salientam DESBOIS, FRANÇON eKEREVER:

«L'Acte de Stockolm, en effet, tout en ayant été signé par de nombreux Etats, n'apas, en definitive, reçu bon accueil parce que les dispositions générales de fond étaient liées a un Protocole, dit «intégré», qui avait éte établi en faveur des seuls pays en voie de developpement.» (o. cit., p. 9).

Observou-se então que não se mostrava adequado para os fins desejados, como atesta DOCK, verbis:

«L'expérience et le temps ayant démontré que le Protocole en restreignant trop systématiquement, le niveau de protection ne représentait, pas une bonne politique de développement.» («Radioscopie du droit d'auteur contemporain», p. 425).

De um lado, especialmente face a razões econômicas e na defesa de seus autores, os países desenvolvidos não o ratificaram, enfatizando DESBOIS que: 
«Les pays développés n'ont pas ratifié l'Acte de Stockholm (1967) parce que les mesures prises en faveur des pays en voie de développement leur ont paru à la réflexion porter de trop profondes atteintes aux intérêts fondamentaux des auteurs.» (o. ult. cit., p. 79).

Também os países em desenvolvimento não aderiram à revisão de Estocolmo, especialmente face à constatação de que as regras do Protocolo, no fundo, escondiam o intento maior de obtenção ou de manutenção dos mercados que aqueles Estados representavam.

Com isso, ruiu-se o sistema edificado em Estocolmo, permanecendo, no plano convencional, intacta a regulamentação anterior, obtida em Bruxelas, em 1948.

Persistindo, no entanto, o citado movimento, com as premissas de que a) imprescíndivel se fazia a difusão cultural nos países em desenvolvimento e b) necessária era a compatibilização entre as disposições da Convenção de Berna e as da Convenção Universal de Genebra, de 1952, adotou-se, nos trabalhos das organizações internacionais, a orientação de proceder-se à revisão dos textos dos dois diplomas em questão.

Assim é que, em Paris, em 1971, na efetivação da mencionada revisão, foi aprovado um Anexo à Convenção de Berna, integrado às suas normas, para substituir o citado Protocolo, o qual está em vigor desde 10-10-74, depois de inseridas, no corpo da Convenção Universal - que já contemplava regras sobre tradução - normas abrandadas para os países em desenvolvimento. CV DE SANCTIS: «Le revisioni», cit., p. 131 e segs.; dentre outros textos).

Com efeito, conforme explicam DESBOIS, FRANÇON e KEREVER, convenceram-se os convencionais de que o Ato de Estocolmo -.- «a paru à la réflexion imposer des sacrifices excessifs aux pays développés, de sorte qu'il a fallu mettre de nouveau la toile sur le métier à Paris en juillet 1971: le Protocole a cédé la place à une Annexe, moins audacieuse, mais les dispositions générales de fond, applicables aux pays développés, sont demeurées telles qu'elles avaint éte elaboriées à Stockholm quatre ans plus tôt». (o. e loc. cit.).

Objetivava-se, de um lado, quanto à Convenção Universal, a introdução, em seu corpo, de normas atenuadoras dos direitos de reprodução de radiodifusão e de tradução para os países em desenvolvimento, sem necessidade de reciprocidade material.

De outro lado, quanto à Convenção de Berna, pretendia-se, basicamente, desvincular de seu conjunto o texto do Protocolo referido, bem como a inserção de norma tendente a permitir a aplicação, pelos países em desenvolvimento, da Convenção Universal revista.

$\mathrm{Na}$ reunião de Paris, chegou-se à dupla revisão - cujas regras vigem até o momento - na qual se obteve, de modo geral, o reconhecimento das idéias assinaladas, para cujo êxito contribuiu a premissa básica, assentada no plano do Direito de Autor Internacional, da ne- 
cessidade de reexame periódico de suas Convenções, para o ajuste às novas realidades econômicas, políticas e sociais, de um lado, e ao progresso das técnicas de comunicação, de outro. (Sobre a reunião de Paris e seus reflexos, V. DESBOIS, FRANÇON e KEREVER « o. cit.; DE SANCTIS: o. ult. cit.; GALTIERI: o ult. cit.; DESBOIS: o cit.; DOCK: o ult. cit. e tb. «La Convention Universelle sur le droit d'auteur revisés à Paris de 24 juillet 1971», in «Homage a Henri Desbois», Paris, Dalloz, 1974, p. 3 e segs.).

Assim é que, na Convenção Universal, as disposições sobre países em desenvolvimento foram inseridas nos arts. $\mathrm{V}$ bis, $\mathrm{V}$ ter e $\mathrm{V}$ quater, que cuidam, respectivamente: a) da noção, adotando a da Assembléia Geral das Nações Unidas; b) de licenças obrigatórias concernentes a tradução, estabelecendo condições, procedimento e regime, no qual se exige a autorização simultânea do autor, de organismo internacional e de centro nacional, e o pagamento da remuneração fixada; c) de licenças obrigatórias quanto a reprodução de obras, com a mesma disciplinação.

As normas em questão constituem regime unilateral, não dependendo, portanto, de reciprocidade, presente nas relações entre países da Convenção.

Observa-se, de início, em comparação com o texto anterior, que mais restrito se apresenta o campo das limitações e delimitado com mais técnica, a par de estabelecer condições e formalidades múltiplas tendentes a, uma parte, garantir um certo rigor na sua concessão e, outra, assegurar ao autor (ou o seu editor) a participação no procedimento de aprovação, com a conseqüente percepção da remuneração cabivel.

Com respeito à revisão da Convenção de Berna, efetivou-se a transposição dessas disposições, sob a forma de «Anexo» a seu texto.

Adotou-se, em sua esquematização, a seguinte ordem: a) norma geral de conceito (art. I); b) regras particulares à tradução, (art. II); c) à reprodução (art. III); e d) regras comuns às duas situações (art. IV: com diligências impostas ao requerente; prerrogativas do direito moral; proibição de exportação; fixação e regulação do montante da remuneração).

A par disso, foram incluídas disposições próprias, referentes a: a) opção por um regime especial de tradução, irreversível, pelo qual se prevê a cessação do direito em caso de não utilização em dez anos da primeira publicação (art. V) e b) aplicação antecipada (art. VI), pela qual, mesmo antes da ratificação do Ato de Paris, permite-se ao país interessado adotar as duas licenças ou a referida opção, nas condições previstas.

Verifica-se que, de um lado, foram absorvidas, em sua essência, as regras da Convenção Universal, apenas sob nova formulação, mais técnica, na separação entre as licenças de reprodução e de tradução e 
o posterior englobamento das condições comuns em uma só disposição. De outro lado, instituiu-se a alternativa citada e abriu-se importante válvula de integração, por meio da aplicação antecipada, que introduziu na matéria.

Outrossim, na análise geral dessas limitações, constata-se que se concentram, principalmente, no sacrifício de direitos patrimoniais de autores de países desenvolvidos, sobre os quais se pretende fazer recair os ônus para o almejado desenvolvimento.

\section{A lei-tipo proposta pelas organizações internacionais}

Ao lado das limitações expostas, cristalizou-se, a nível internacional, orientação de definir-se certas normas-padrões como diretrizes para a normatização da matéria no direito interno dos países em destaque: a denominada «lei-tipo» para os países em desenvolvimento.

Esse outro movimento, defluente do conflito que vimos analisando - encontra raízes também nos países africanos de independência recente, motivados pela intenção de alcançar, pela cooperação, denominadores comuns na instituição de legislação sobre Direito de Autor, valendo-se, inclusive, da experiência haurida pelos países desenvolvidos.

A idéia de lei-tipo surgiu, não como a de um figurino, que se procurava impor aos países em questão, mas como sugestões, que seriam adaptadas, a cada um, em consonância com as respectivas necessidades.

Funcionaria com um repositório dos direitos mínimos previstos nas Convenções, que seria, depois, ajustado à situação de cada Estado interessado, em função de suas condições sociais, políticas e econômicas.

Nesses textos - como salienta MASOUYÉ - a organização internacional «élabore, avec des experts venant des Etats en vois de développement, des lois-types à l'intention de ces Etats sur divers aspects de la propriété intellectuelle» (o. cit., p. 323 e 324).

$\mathrm{E}$ adiante, quanto à sua natureza, acentua:

«Il s'agit évidemment de modéles dont les législateurs peuvent s'inspirer et qu'ils ont la faculté, le cas échéant, de modifier pour tenir compte du régime juridique en vigueur ou des impératifs économiques qui sont propres à de tels Etats». (o. cit., p. 324), (V. tb. do mesmo autor, no mesmo sentido: «Le Droit d'auteur et le développment», in «Il Diritto di Autore», 1977, p. 112).

Seus defensores consideravam limitadas as disposições da Convenção, convencendo-se de que não são de molde a resolver o problema da melhoria rápida de suas condições culturais.

Conscientizaram-se então da necessidade de conhecer-se com clareza os problemas comuns e, vencida essa etapa, a de alcançar, com uma legislação uniforme, os seus desideratos. Daí, puseram-se a trabalhar a idéia de uma lei-tipo, para uso comum dos países africanos. 
Em diferentes reuniōes internacionais foi discutida e recomendada a sua adoção, destacando-se, nesse contexto: a) a recomendação da União Africana: Brazzaville, de 5 a 10-8-63; b) o projeto preparado pelo Comitê de especialistas africanos: Genebra de 30-11 a 4-12-64; c) as conclusões do Seminário sobre Direito de Autor da Ásia Oriental: Nova Delhi, 23 e 30-01-1967; d) as do Seminário africano sobre propriedade intelectual: Nairobi, 16 a $20-10-72$; e) o projeto do Comitê de especialistas: Abidjan, 8 a 12-10-73., este apresentado à OMPI e à UNESCO; f) o de outro Comitê de representantes de países em desenvolvimento, aprovado em Tunis: 23-02 a 02-03-1976, dando aso à «lei-tipo de Tunis», modelo hoje adotado pelas organizações internacionais na matéria (OMPI e UNESCO).

Para a formulação da lei-tipo, duas premissas básicas foram fixadas: a) a da necessidade de compatibilização de seu texto com o das convenções internacionais; b) o da adaptalidade de seu texto aos diferentes sistemas legislativos vigentes, de origem romana e de origem anglo-saxã.

$\mathrm{Na}$ consecução da lei-tipo que veio a ser aprovada (de Tunis), adotaram-se como diretrizes gerais: a) a observância da terminologia da Convenção de Berna; b) a técnica de definições, sobre as principais figuras jurídicas previstas em seu contexto; c) a incorporação dos sistemas de licenças de reprodução e de tradução previstos na revisão de Paris (V. «Tunis Model Law of Copyright», UNESCO e OMPI, Paris, e Genebra, 1976).

$\mathrm{Na}$ esquematização da lei-tipo de Tunis, que se compõe de dezoito seções, incluem-se, de inicio, normas de caráter geral e, depois, as de cunho específico, completando o seu contexto dois apêndices, "A» e «B», sobre as licenças para tradução e para reprodução.

Começa por definir as obras protegidas (seção I), inclusive as derivadas (seção II), indicando as que não recebem amparo (seção III).

Versa, ao depois, os direitos pecuniários (seção IV) inclusive o direito de sequência (seção IV-bis) e os direitos morais, (seção V), com disposição especial sobre obras de folclore (seção VI).

Cuida, em seguida, do uso comum (seção VII); das produções efêmeras (seção VIII); das limitações para tradução (seção IX) e para reprodução (seção $\mathrm{X}$ ).

Seguem-se: a indicação dos titulares dos direitos (seção XI); a transferência dos direitos (seção XII); a duração dos direitos patrimoniais (seção XIII, em que fica entre os limites de 50 a 25 anos depois da morte do autor); e as organizações de autores (seção XIV).

Regula, adiante, as infrações e as penalidades (seção XV), delimita o seu campo de aplicação (seção XVI), versa sobre o domínio público remunerado (seção XVII), terminando por lançar as definições dos principais conceitos utilizados (seção XVIII).

Os anexos disciplinam as licenças referidas. 
Da análise de seu contexto, depreende-se a real influência das Convenções, especialmente a de Berna; a prevalência da técnica do direito anglo-saxão na disposição e na redação dos textos e, na matéria de fundo, a preocupação em fixar-se os direitos mínimos previstos no ius-convencionais.

$\mathrm{Na}$ substância, ainda tende para a orientação latina, prevendo, por expresso, os direitos morais, com os reflexos naturais na problemática da transferência de direitos.

Outrossim, ainda no plano das organizações internacionais, não se pode deixar de registrar os seus programas de assistência, de intercâmbio e de divulgação dos direitos de autor em todo o mundo, nos quais empresta ênfase especial aos países em desenvolvimento, dentro do espírito apontado.

\section{Reflexos no direito interno dos paises em desenvolvimento}

Face aos pressupostos já enunciados, diferentes reflexos tem produzido, nos países em desenvolvimento, o movimento internacional em prol de sua expansão cultural.

Desde a indiferença legislativa à aceitação dos mecanismos de licença, e da preservação de sua legislação à aceitação das fórmulas definidas na lei-tipo, posições várias são detectadas na análise de sua situação.

Com efeito, a maioria dos paises em desenvolvimento, especialmente do continente africano, editou legislação especifica para os direitos de autor e logo em seguida à sua libertação política (à relação citada, podem-se ainda acrescentar, as leis do Burundi, de 4-5-78; Mali, 12-7-77; Nigéria, de 24-12-70; Guiné, de 9-8-80; Tanzânia, de 14-12-66; Uganda, de 22-6-64).

De outras partes do denominado «Terceiro Mundo» também surgiram, a par das citadas, leis próprias sobre a matéria (como as: de Irã, de 1969; Malásia, de 1969; Nepal, de 1966; Paquistão, de 1962 (com alterações de 1972); Filipinas, de 1972; Sri Lanka, de 1979; Nova Zelândia, de 1962; Haiti, de 1968).

Outros, no entanto, nem sequer a esse passo chegaram, mantendo textos normativos sobre a matéria em velhos Códigos e em leis ainda do século passado (como: Costa Rica, de 27-6-1986; Nicarágua, Código Civil; Panamá, Código Administrativo; Honduras, lei sobre patente de invenção; Etiópia, Código Civil; Síria e Camboja, Código Penal).

Dos países que lançaram legislação própria para o Direito de Autor, aqueles que mais se aproximam do sistema convencional são os africanos, tendo poucos abraçados, legislativamente, os regimes de licença de tradução e de reprodução, e absorvendo outros a técnica e mesmo a substância da citada lei-tipo. 
Dos países que introduziram a licença compulsória para tradução, publicação e radiodifusão de obras, de modo frontal, se encontra a Algéria, cuja lei manda observar, no caso, as condições fixadas nas Convençōes (arts. 30 a 34).

Também o México permite restrições aos direitos autorais quanto a obras necessárias à difusão da cultura, declaradas como tal pelo governo central e observadas as condições previstas (arts. 62 a 71). Na Malásia (lei de 1969 , art. $18, \mathrm{n}^{0}$ 2) se consigna essa autorização para tradução.

Da mesma forma, a Tunísia admite que, para fins culturais, a autoridade competente autorize a reprodução de obras necessárias às suas atividades (art. 11, observadas as condições fixadas (arts. 16 e 32).

Reforma feita no Paquistão prevê a declaração, pela autoridade competente, de não incidência dos direitos na reprodução, tradução ou adaptação de obras para ensino em entidades oficiais (Emenda de 1972, seção 37). Assim também é a posição do Nepal (art. 12).

Por fim, a lei de Cuba, muito mais em função da ideologia abraçada, contempla, por expresso, a licença para reprodução de obras de interesse social (art. 37).

De outro lado, contêm restrições a obras estrangeiras em caso de não existência de reciprocidade - e isso já em função do próprio mecanismo geral das convenções — as leis de: Bangladesh (seç. 55); Equador (art 5\%); Egito (art. 49); India (seç. 40 e 41); e Marrocos (art. 63), dentre outras.

Outros países, ao revés, permaneceram fiéis ao sistema tradicional, tanto de influência latina, quanto anglo-saxã, portanto, mantendo seu direito positivo no mesmo nível das legislações dos países desenvolvidos. $\mathrm{E}$ essas nações constituem a sensível maioria no elenco das incluídas no citado conceito.

Por fim, em incursão pela respectiva legislação, colhe-se que, quanto ao prazo de duração, é que as convenções mais obtiveram a adesão desses países, tendo grande parte acolhido os limites nelas propostas (como, dentre outras, as leis de Senegal; Egito; Zâmbia; Âfrica do Sul; India Venezuela; Algéria; Austrália).

$\mathrm{Na}$ verdade, como se observa, de pequeno alcance prático tem sido o movimento em questão, de modo que os países em desenvolvimento permanecem, de uma forma geral, admitindo apenas as limitações clássicas e na função de balizas ao exercício dos direitos de autor - que o interesse da coletividade suscita - e, como frisa FABIANI, «per la sua fruizone como strumento di comunicazione e di participazione al colloquio tra il creatore dell'opera ed il pubblico che la apprende», o qual «se realizza, paradosalmente, sia attraverso il riconoscimento del diritto dell'autore sia attraverso le norme limitative di questo stesso diritto» (cit., p. 163 e 164). 
Os resultados previstos não foram, portanto, de aclance pragmático considerável, face aos esforços levados a efeito nas conclaves e estudos realizados, mas, de qualquer sorte, não se podem olvidar os reflexos indiretos decorrentes, especialmente os de divulgação e de sedimentação dos princípios básicos que inspiram o Direito de Autor.

Infere-se, pois, do posicionamento citado, que os países em questão, na busca do equilíbrio entre o interesse público e o interesse privado, chegaram à conclusão de que atende melhor à respectiva situação uma proteção eficaz às criações intelectuais de seus nacionais do que as atenuações e exceções propugnadas.

Assim é que, nos países sul-americanos que mais recentemente editaram leis especiais sobre a matéria, como o Chile (lei de 28-8-70), o Brasil (lei de 14-12-73) e o Equador (lei 13-8-76, a tônica foi a da conformação aos princípios e às regras básicas integrados nas legislações européias de maior nivel de amparo aos criadores, em especial à lei francesa de 1917, inegavelmente, a de mais amplo espectro na defesa dos direitos dos autores.

Ressalte-se aliás, que em nosso país, doutrina, legislação e jurisprudência - como temos apontado - são uníssonas na preservação das prerrogativas dos autores intelectuais, que encontram respaldo também na ação do órgão máximo de fiscalização, consulta e assistência no setor; o Conselho Nacional de Direito Autoral (lei 5.988/73: art. 116), que tem desenvolvido profícuo labor pelas realização prática desses direitos, dentro da orientação geral enunciada.

Ante ao exposto, as reflexões sobre o tema levam-nos a algumas conclusões que nos parecem inquestionáveis no estágio atual.

De início, a) o Direito de Autor segue sendo reconhecido, nos dois sistemas básicos existentes (latino e anglo-saxão), tanto doutrinária, quanto legislativamente, dentro das características com que neles ingressou. Assim, subjetivista e privatístico, mostra-se no sistema latino, com as concessões delineadas; e objetivista, mas privatístico no sistema anglo-saxão, admitidas as limitações clássicas. A proteção ao autor, em um, e à obra, em outro, são os pontos essenciais dos sistemas.

Com isso, o pensamento liberal - de que se gerou - continua prevalecendo nessa matéria, exatamente em função da necessidade de mostra, com respeito à parte ocidental, ANDRÉ KEREVER, que examina a situação desse direito na Alemanha, na França, na Inglaterra e em Portugal ( Le droit d'auteur en Europe Occidentale», in «Hommage a Henri Desbois», Paris, Dalloz, 1974, p. 36).

Esse mesmo quadro prospera nas Américas, com as poucas exceções apontadas, nas leis de todos os países integrantes, conforme observamos na respectiva análise. Assim ocorre, por exemplo, dentre outras, na leis do Brasil, (citada) Argentina (lei 11.723, de 2-10-57); Venezuela, (lei de 29-11-62); Chile (de 28-8-76); México, (lei de 29-12-56); Uruguai, (lei de 17-12-37). 


\section{Conclusões}

Dando mostra dessa orientação, assinala, na Argentina, MIGUEL ANGEL EMÉRY - na conclusão de seu estudo sobre rumos atuais desse Direito nas Américas, com destaque para as leis do Chile, do Brasil e do Equador - que as leis sul-americanas» restringen la limitaciones y no conceden licencias para la utilización compulsiva de las obras», sob a premissa básica da «ratificación del reconocimento pleno al autor de un derecho erga omnes para la utilización de sua obra...» ( «Rumbos actuales de la legislación autoral en las Americas», in «Revista Interamericana de Direito Intelectual», 1978, $\mathrm{n}^{\circ} 2$, p. 81).

$\mathrm{Na}$ doutrina, uníssona é, tanto na América do Sul, como na do Norte, a tendência dos respectivos escritores em prol da preservação do Direito de Autor nos níveis tradicionais.

Com efeito, conforme assinala, na Argentina, HECTOR DELLA COSTA, o Direito de Autor nas Américas se lastreia em «princípios da doutrina e da legislación européia», «a las cuales se adaptan más cómodamente los sistemas latino-americanos y los del mundo de las ex-colonias», ( «El Derecho de Autor y su novedad», Buenos Aires, Cathedra, 1971, p. 163).

Nesse sentido, é que, na Venezuela, FRANCISCO HUNG VAILLANT salienta que a lei autoral foi baixada «aprovechando princípios y soluciones sometidos a prueba en paises con suas tradición e experiencia compatilizados con as convenciones internacionais na materia» (Âlgunos aspectos de la protección del Derecho de Autor en Venezuela», Caracas, Instituto de Derecho Privado, 1965, p. 8).

$E$ que, nesse campo, deve-se prever sistema adequado para a proteção do criador, pois como pondera RICARDO ANTEQUERA PARILLI - que também estuda esse Direito na Venezuela (p. 17 e segs.) - seu objeto «es la tutela del hombre en lo que después de su vida, constituye lo más sagrado: su capacidad de pensar y de sentir» ( «Consideraciones sobre el Derecho de Autor», Buenos Aires, ed. do autor 1977, p. 16).

Assim é que, b) respeitadas as considerações em prol do desenvolvimento cultural - necessário nos países em causa - a verdade é que não se pode sustentar essa expansão lastreada apenas no sacrifício de um setor da coletividade, o intelectual, mas deve, ao revés existir um planejamento adequado e que leve em conta todos os aspectos globais do problema.

Deve haver c) uma conciliação entre os interesses em causa, mas de sorte a que a carga não recaia somente sobre os criadores intelectuais, cumprindo engendrar-se fórmulas que repartam esses ônus pela coletividade em geral, e aproveitando-se, nessa tarefa, das diretrizes oferecidas pelas organizações internacionais, enquanto norteadoras de ação eficaz nessa área. 
Cumpre seja efetuado d) planejamento adequado no campo cultural, desenvolvendo-se política própria, mediante a estimulação das artes, das letras e das ciências, consoante instrumental e técnicas disponiveis em cada país, e atendendo-se sempre, nesse mister, para a tradição e as condições específicas de cada qual.

Por isso é que alguns especialistas criticam a orientação convencional, como CARLOS ALBERTO VILLALBA, da Argentina, quanto à política adotada para os países em desenvolvimento, acentuando que assenta sobre premissa errada - ou seja, o sacrifício dos autores para obter-se o desenvolvimento - acrescentando, ademais, que pouco serviriam as licenças previstas, dadas as formalidades exigidas e que «distraéran a dichos paises de sus verdaderos objetivos en el ámbito de la cultura y en el desarollo de sus proprios recursos humanos y industriales», ( «La protección universal del Derecho de autor en lo que atãne a las Convenciones de Berna y Universal asi como las de Buenos Aires y Washington», in «Revista Interamericana de Direito Intectual», $1978, n^{0} 2$, p. 93 e 94 ).

Outros autores apontam a necessidade de compatibilização, sentida nos países em questão - como bem anota ALGARDI (o. cit. p. 279) - os quais procuraram regular de maneira orgânica a matéria na busca de posicionamento adequado.

Assim, J. RAMON OBON LEON, do México, salienta que, nesse campo, se deve buscar melhores benefícios econômicos para os autores e garantir-lhes segurança social, enfatizando que é «de vital importancia adecuar debidamente los derechos patrimoniales del autor conforme a ese espíritu social», («Lo derechos de autor en México». Buenos Aires, CISAC, 1974, p. 121).

KOVANANG, de Camarões, também realça a importância do reconhecimento dos direitos de autor, salientando que «compte tenue de l,importance de la creación dans le processus de développement»..., «il est incontestable que la reconnaissance d'un droit exclusive au profit du créateur est une consécration de l'effort créatif et, par voie de con sequence, un facteur essentiel de progrés social» (o. cit. p. 240).

Mas, em contrapartida, para os países da Africa, a respectiva legislação deve conter normas «permettant d'assurer une protection adéquate et efficace de leur patrimoine culturel» (o. cit., p. 242).

No mesmo sentido, BENCHENEB, da Algéria, após indicar as limitações e as exceções em seu país fixadas para os direitos de autor, realça que «l'application de ces dispositiones peut être une contribution de plus intéressante à la loute pour le développement culturel, car leur fondement est incontestablement leur utilité pédagogique ou scientifique» (o. cit., p. 246).

Mas, como bem anota, no Uruguai, ROMEU CROMPONE( «problema essencial en esta materia es determinar hasta que punto es conciliable la asistencia cultural a esos paises, con los derechos de los autores a percibir una justa compensación por su creación» e que com a 
harmonização seria dado passo fundamental para o progresso da humanidade».

Adverte então que, se prejudicial aos autores a opção, «cortariamos todo estímulo de futuro y ese ideal se frustaria al cabo de los años» ( «El Derecho de Autor en Uruguay», Montevideo, AGADU, 1977, p. 35).

Com efeito, e) imprescindível é garantir-se aos autores uma proteção eficaz, de sorte a assegurar-lhes os direitos que a tradição e a prática lhes têm consagrado - e as organizações internacionais divulgado, adequadamente - não se esquecendo do relevante papel que desempenham no desenvolvimento das nações, e que valeram a inserção, como um dos direitos fundamentais, nas Declarações Universais de Direitos do Homem e nas Constituições de vários países modernos.

Como bem afirma MASOUYÉ, esse Direito «constitue, dans le monde contemporain, un élément important du processus du dévedoppement».

Por essa razão é que, desanuviando horizontes, arremata; «Si parfois des inquiétudes s'expriment quant à l'avenir du droit d'auteur face à la technologie moderne qui bouleverse les conditions d'utilisation des oeuvres, il faut néanmoins rester optimiste car l'encovragement à la condition premièr de toute promotion sociale, économique et culturelle» («Le Droit d'auteur et le développment», cit., p. 118).

Nas reuniões e conclaves levados a efeito nas Américas essa tem sido a tônica.

Assim, na I Conferência Continental do Instituto Internamericano de Direito de Autor, realizada em São Paulo, em 1977 - de que participamos - dentre as recomendações aprovadas, foi inserida a da uniformização desse Direito na América, sugerindo-se a compatibilização dos sistemas, na medida em que as orientações «tendam ao desenvolvimento do Direito de Autor e respeitem os mais altos níveis de proteção logrados na área» (V. Ata final dos trabalhos; V. tb. «La Propriedad Intelectual», O. M. P. I., 1977, 3ำ trim, p. 143).

Patenteou-se, à ocasião, o alto grau de subjetividade que animava os convencionais, preocupados sobremaneira com a proteção do autor, como criador intelectual.

$\mathrm{Na}$ II Conferência Continental do referido Instituto - de que também participamos e na mesma diretriz apontada - dentre as recomendações aprovadas, figuram também as de unificação da legislação americana e a de ampliação da proteção do Direito de Autor pelo máximo de prazo nelas existente; ( $V$. Ata dos Trabalhos e o compêndio «Los ilícitos civiles y penales en Derecho de Autor», editado pelo Centro Argentino do IIDA, 1981).

Por esses motivos é que, f) inobstante a crise que enfrenta esse Direito - em especial frente a utilização indiscriminada de processos 
modernos de reprodução e de representação de obras intelectuais, que temos acentuado em vários trabalhos - a verdade é que subsistirá, em todo o seu esplendor, enquanto houver preocupação pelos valores básicos do homem.

Com razão é que DESANTES, na Espanha, enfocando a crise do Direito de Autor (o. cit., p. 94), assinala que no presente é ela «una inflexión angular entre su pretérito y su futuro», e depois de examinar essa problemática com relação aos diferentes meios de comunicação da obra, acentua depois que esse direito é «el potenciador jurídico de todo el progreso técnico de los médios de comunicación» e se encontra «unido indisolublemente a cualquier proceso de comunicación de masas», (o. cit., p. 108).

No mesmo sentido BARBARA RINGER - que se detém sobre as modificações impostas nas comunicações pelo avanço das técnicas salienta, nos EUA que a sua situação atual faz redobrar a necessidade de assegurar-se remuneração condigna aos criadores, enfatizando que o Direito de Autor, «comme la condition juridique de la création intellectuelle», "subsistera tant que l'homme continuera à faire preuve d'activité créatice». $\mathrm{E}$ concluindo, profetiza: «au sens large de régime qu'une société choisit d'appliquer à ses éléments créateur existera toujours, quol qu'il advienne». (Le Droit d'auteur et l'avenir de la création intellectuelle», in «Le Droit d'Auteur», 1976, Junho, p. 158 e segs.).

Dentro desse contexto, é que, na Argentina, CARLOS MOUCHET assinala que, embora institucionalizada a sua limitação no tempo, ainda se deduzem argumentos a favor da perpetuidade ( $\mathrm{E}$ l domínio público pagante en materia de uso de obras intelectuales», Buenos Aires, Fondo Nacional de Las Artes, 1970, p. 17).

Isso significa que tem imperado a necessidade de «reconhecimento absoluto, completo e perpétuo», de que falava, no Brasil, no começo do século, SAMUEL MARTINS o. cit., p. 16).

$\mathrm{E}$ essa tendência $\mathrm{g}$ ) deve acentuar-se, porque, de um lado, o Direito de Autor é direito natural do homem, e, de outro, o progresso intelectual depende de criações do espírito e essas somente são possiveis - como é intuitivo - em um sistema que garanta ao autor os proventes dela defluentes, cumprindo, pois, aos interessados - governantes, legisladores, estudiosos e outros - assegurar que as técnicas introduzidas para a reprodução e a representação de obras intelectuais não prejudiquem os direitos em causa, como temos alertado em vários estudos.

Já vaticinava, entre nós, OSVALDO SANTIAGO, que, «Com o avançar dos anos e o progresso da humanidade, o direito autoral será decerto, cada vez mais incentivado e respeitado em todos os quadrantes do globo, quaisquer que sejam as raças, religiões, costumes e ideologias dos povos da Terra» (《Aquarela do Direito Autoral», Rio, 1948, p. 22).

De outro lado, apercebendo-se da relevância da problemática da remuneração autoral, registra MASOUYÉ que: 
«L'experiénce récente a en effet montré que l'ennichissenment du patrimonie culture national dépendait directement du niveau de la protectionaccordeé au droit d'auteur: plus ce niveau est élevé, plus les auteurs sont encouragés à faire oeuvre de création; plus il y a de créations intellectuelles, plus s'elargit le rayonnement culturel du pays considéré... .» (o. cit., p. 117).

Dissipa-se, com isso, a preocupação manifestada - quando de decisão proferida por sua Corte Suprema sobre transmissão por satélite - por MICHEL F. MAYER, nos EUA, em que pugnava pela necessidade de remuneração aos criadores na veiculação de suas obras feitas por aquele meio. ( $\mathrm{A}$ decline of protection for creative rights?», in R.I.D.A., 1971, LXX, p. 87 e segs.).

Nesse sentido, é que na Inglaterra, STEPHEN STEWART, ao estudar a evolução da legislação britânica sobre a matéria, alcança, dentre outros, as conclusões de que se deve «continuer de concevoir avec souplasse les notions d'auteur et d'oeuvre», «étendre le droit d'auteur aux nouvelles formes de communication par lasquelles les auteurs atteignent le grand public» e «améliorer encore la perception des redevances. . ( («Deux cents ans», cit., p. 225).

Razão assistia a LAMARTINE - uma das principais expressões da literatura francesa - que, nos longínquos anos em que vivia, pré-revolucionário, profetizava:

«En vertu d'une induction naturelle et just, le jour devait aniver où l'oeuvre de l'intelligence sepait reconnue un travail utile, et les fruits de ce travail une propriété».

Com efeito, o Direito de Autor constitui direito de cunho personalíssimo, sob o seu aspecto subjetivo, representando verdadeiro «princípio de direito moral», como afirmava, na França STANISLAS DE GORGUETTE D' ARGOEUVES ( $(\mathrm{Du}$ droit moral de l'auteur sur son oeuvre artistique ou littérarie», Lille, Camille Robbe, 1924, p. 38).

Não devem, em nosso entender, h) existir limitações à circulação da criação intelectual e à participação do autor em todos os processos de utilização, para que a obra realize a sua vocação universalista, como bem acentua, no mesmo país, STOYANOVITCH, verbis:

«Une oeuvre de l'esprit possède bien une nationalité elle de son auteur on elle du pays ou elle a vu le jour, mas elle ne connâit point de frontière, elle aspire à l'universalité» (o. cit., p. 41) (V. tb. ALGARDI: 0 . cit., p. 272).

Ante todo o exposto, permitimo-nos repetir aqui as observações, feitas alhures, de que «quanto mais se insere a cultura como objetivo constitucional dos Estados modernos e mais aparatos e dispositivos de reprodução e de representação de obras intelectuais são introduzidos na prática, mais se exalça a preocupação pelos valores individuais que esse Direito protege e mais se reafirma ele como direito vivo, atuante 
e dinâmico» («Direito de Autor na obra publicitária», S. Paulo, R.T., 1981, p. 16).

Respeitadas as ponderações feitas, o Direito de Autor poderá i) desempenhar o verdadeiro papel de sustentáculo da evolução cultural do país, na proteção de sua expressão mais nobre e mais enaltecedora, que é a criação intelectual.

Por outras palavras, é pela manutenção do status protecionista e pela ampliação dos mecanismos práticos de percepção de direito que se poderá obter o progresso cultural dos países em desenvolvimento, apoiado - é intuito - por política adequada para o setor.

Por todas as razões expostas, e que, com as conotações acentuadas, acreditamos venha o Direito de Autor a sobreviver, atravessando diferentes épocas, como o único instrumento jurídico eficaz para o efetivo amparo às criações intelectuais e para o real estímulo ao desenvolvimento cultural dos povos, quaisquer que sejam os respectivos índices, o grau tecnológico correspondente e o nível de maturação intelectual alcançado. 